San Jose State University

SJSU ScholarWorks

Master's Theses

Master's Theses and Graduate Research

1994

\title{
Changes in representations of nature in Thomas Hardy's two great novels, Far from the madding crowd and Tess of the d'Urbervilles
}

Lisa S. Palmer

San Jose State University

Follow this and additional works at: https://scholarworks.sjsu.edu/etd_theses

\section{Recommended Citation}

Palmer, Lisa S., "Changes in representations of nature in Thomas Hardy's two great novels, Far from the madding crowd and Tess of the d'Urbervilles" (1994). Master's Theses. 862.

DOI: https://doi.org/10.31979/etd.zf9f-z2nx

https://scholarworks.sjsu.edu/etd_theses/862

This Thesis is brought to you for free and open access by the Master's Theses and Graduate Research at SJSU ScholarWorks. It has been accepted for inclusion in Master's Theses by an authorized administrator of SJSU ScholarWorks. For more information, please contact scholarworks@sjsu.edu. 


\section{INFORMATION TO USERS}

This manuscript has been reproduced from the microfilm master. UMI films the text directly from the original or copy submitted. Thus, some thesis and dissertation copies are in typewriter face, while others may be from any type of computer printer.

The quality of this reproduction is dependent upon the quality of the copy submitted. Broken or indistinct print, colored or poor quality illustrations and photographs, print bleedthrough, substandard margins, and improper alignment can adversely affect reproduction.

In the unlikely event that the author did not send UMI a complete manuscript and there are missing pages, these will be noted. Also, if unauthorized copyright material had to be removed, a note will indicate the deletion.

Oversize materials (e.g., maps, drawings, charts) are reproduced by sectioning the original, beginning at the upper left-hand corner and continuing from left to right in equal sections with small overlaps. Each original is also photographed in one exposure and is included in reduced form at the back of the book.

Photographs included in the original manuscript have been reproduced xerographically in this copy. Higher quality 6" x 9" black and white photographic prints are available for any photographs or illustrations appearing in this copy for an additional charge. Contact UMI directly to order.

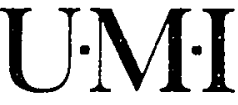

University Microfilms internatıonal

A Bell \& Howell Information Company

300 North Zeeb Road. Ann Arbor, Ml 48106-1346 USA

$313 / 761-4700 \quad 800 / 521-0600$ 

Order Number 1359045

Changes in representations of nature in Thomas Hardy's two great novels, "Far from the Madding Crowd" and "Tess of the d'Urbervilles"

Palmer, Lisa S., M.A.

San Jose State University, 1994

Copyright (C)1994 by Palmer, Lisa S. All rights reserved.

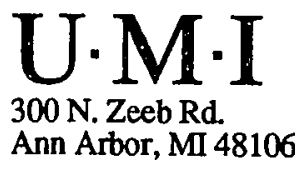





\title{
CHANGES IN REPRESENTATIONS OF NATURE IN THOMAS HARDY'S \\ TWO GREAT NOVELS, FAR FROM THE MADDING CROWD \\ AND TESS OF THE D'URBERVILLES
}

\author{
A Thesis \\ Presented to \\ the Faculty of the Department of English \\ San Jose State University
}

In Partial Fulfillment

of the Requirements for the Degree

Master of Arts

by

Lisa S. Palmer

August 1994 
01994

Lisa S. Palmer

ALL RIGHTS RESERVED 
APPROVED FOR THE DEPARTMENT OF ENGLISH

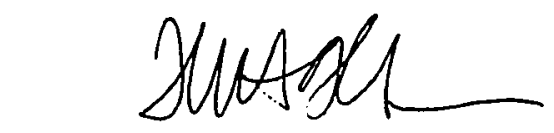

Dr. William Wilson

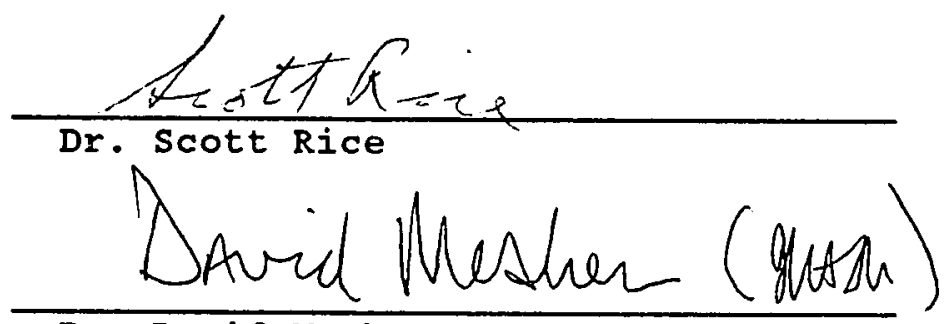

Dr. David Masher

APPROVED FOR THE UNIVERSITY

In. Lour Leuracdenustei 
ABSTRACT

CHANGES IN REPRESENTATIONS OF NATURE IN THOMAS HARDY'S TWO GREAT NOVELS, FAR FROM THE MADDING CROWD AND TESS OF THE D'URBERVILLES

by Lisa S. Palmer

This thesis shows that, from conventional classical thinking to a contemporary scientific view, nineteenthcentury philosophy and science influenced Hardy's thinking and consequently his writing. It examines his early formal and tutorial education, showing the depth of his classical and religious training as embodied in Far from the Madding Crowd. Philosophical influences, including English and continental thinkers, moved Hardy away from standard religious and classical explanations to a personal synthesis of his background and contemporary scientific influences particularly within the biological sciences such as Darwinism.

Tracing Hardy's development reveals a clear weakening of the traditional mythological vision of nature, particularly weather imagery, and its replacement by a scientifically grounded view resulting in a more realistic treatment of plot and character in Tess of the d'Urbervilies than in Far from the Madding crowd. In weighing the acceptance of more "natural," instinctual behavior over that endorsed by society, Hardy anticipated the twentieth century. 
FOR MY HUSBAND, JIM 


\section{ACKNOWLEDGMENTS}

I would like to thank Dr. William Wilson for his continuing invaluable help in the direction and pursuit of this thesis and for steering me from irrelevance to significance. I am grateful for analytical reading by $\mathrm{Dr}$. Scott Rice and Dr. David Mesher.

Also, I appreciate the experience afforded me by the 1992 Thomas Hardy Society Conference in Dorchester, England, and specifically Professors Timothy Hands and Peter

Widdowson for sending to me copies of their lectures delivered at the conference as Works in Progress. 
TABLE OF CONTENTS

Introduction . . . . . . . . . . . . . . . . . 1

CHAPTER

I. Hardy's Intellectual Background:

From Nineteenth-Century Thought

Toward More Scientific Reasoning . . . . . . . . 2

II. Far from the Madding Crowd:

The strong Element of Myth and

Conventional Thinking about Nature . . . . . . 44

III. Tess of the d'Urbervilles:

Science, Myth and the Realistic

Development of the Novel . . . . . . . . . 75

IV. Conclusion . . . . . . . . . . . . . 96

WORKS CITED ..................... 108 


\section{INTRODUCTION}

This paper will show that, from conventional classical thinking to a contemporary scientific view, nineteenthcentury philosophy and science influenced Hardy's thinking and consequently his writing. The first chapter will detail his early formal and tutorial education, showing the depth of his classical and religious training as embodied in Far Erom the Madding Crowd. Philosophical influences will include English and continental thinkers who will move hardy away from standard religious and classical explanations to a personal synthesis of his background and contemporary scientific influences. Hardy accepted the idea of Darwinism as fact and did not regard the idea of evolution as a threat to religious thinking. The second chapter of this thesis considers the mixture of standard classical and biblical mythology in Far from the Madding Crowd with his imagined contemporary culture of Wessex. The third chapter explores the weakening of this mythological vision of nature and its replacement by a scientifically grounded view, resulting in a more realistic treatment of plot and character. 
CHAPTER I

Hardy's Intellectual Background:

From Nineteenth-Century Thought

Toward More Scientific Reasoning

With his bookish training by a nineteenth-century scholar, it is natural that Thomas Hardy's early novels were replete with images and references from Christian theology, classical mythology and the works of scholars and literary figures such as Shakespeare, Milton and the Romantics. God or the gods, or at least their influence, still seemed to be present in life and in the landscape. Nature expressed the wrath, benignity, indifference, or blessing of some allpowerful manipulator. And weather (still Britain's chief topic of casual conversation) was an indication of the presence and moods of these loving, punishing forces.

As Hardy matured as a writer, his use of imagery changed from copious mythical and biblical reference in Far from the Madding Crowd to a more restrained use of classical legend in Tess of the d'urbervilles, resulting from his increased awareness of the scientific thinking of this time. My analysis of Hardy's background in the inheritances and thinking of his time and its influence on his work, 
particularly the novels, will involve three areas of thought: the mythic, the philosophical, and the scientific, while the romantic influence will be reserved for Chapter II as perhaps having the greatest influence on such elements as tone, mood, and style, and the poetic attitude, more than on the fundamental thinking of the novelist.

Weather imagery will be prominent among the examples of myth from nature because there exists no better conveyor of the tone and mood of the surroundings, their propensity for change, alterations between light and dark, transcendent beauty and dire physical threat. One might ask why emphasize weather imagery when Hardy is famous for more intellectually involving and perhaps more satisfying imagery, such as the extended metaphor of the hunt as pursuit of an innocent victim in Tess? ${ }^{1}$ All those symbols and metaphors make great reading but, perhaps even more important when all the novels are considered, they are also a unifying force in landscape. Ronald Blythe in his Introduction to the Penguin edition says that Far from the Madding Crowd announced Hardy's arrival as a great writer

1 The metaphor of the hunt finds Tess the victim, throughout almost the whole length of the novel from the bloody death of the Durbeyfield horse necessitating her going to see Alec in the shadows of the Chase, to the ancient d'Urbervilles tomb scenes, Alec's blood on the threshing machine and also on the ceiling of the boarding house, and finally the Druid temple stonehenge with the innocent sacrifice on the great stone altar. 
and that it is also "the peak of his literary innocence" (11). He adds that no subsequent writer has ever been "able to succeed it in its penetrating original view of the English countryside. . . Although literature has many examples of a little confined territory being put to use for the widest possible philosophical purpose . . only Shakespeare compares with Hardy in his rich and inspired manipulation of its simple assets" (12). Virginia Woolf in The Novels of Thomas Hardy comments on the reality as well as artistry which Hardy's use of landscape provides: "There is, in the first place that sense of the physical world which Hardy more than any novelist can bring before us; the sense that the little prospect of man's existence is ringed by a landscape which, while it exists apart, yet confers a deep and solemn beauty upon his drama" (401). Speaking of Hardy's sometimes awkward delineations of the relations of men and women, she adds: "If we do not know them in their relations with each other, we know them in their relations to time, death, and fate. If we do not see them in quick agitation against the lights and crowds of cities, we see them, against the earth, storm, and the seasons" (401). Hardy chose deliberately to limit his landscape to Wessex, embracing an area he knew and weather he fully recognized. He was born to it; he knew the scene absolutely. One of his characters, Henchard, neglects a 
weather doctor's warning, and this presumption is a contributing cause of his catastrophe.

Weather images give the pleasure of instant sharing in the scene rather than asking the reader to figure out parallels, psychological implications, or human relationships. They do not interrupt the flow of narrative; rather, they enhance our vision of the place and the characters who move within it. Weather imagery is therefore perhaps Hardy's prime medium of choice to give the reader a sense of being in Wessex, of walking around Dorchester, of starting out on a dusty road to Talbothays.

MYTH AND RELIGION

The term "mythic" includes the presence of God or gods as an explanation of the First Cause. Hence, myths can have two-fold sources in Hardy's nineteenth century: either religious as in Judeo-Christian accounts of events recorded in the Bible, or the narration of imagined interactions between the gods and man as recorded in the stories of ancient Greek and Roman mythology.

The religious influence of the old and New Testaments on Hardy's imagery was not unusual for a young man growing up in Victorian England. An early influence on Hardy was the Authorized Version of the Bible. Besides having knowledge of the Bible, Hardy worshipped as a boy at 
Stinsford Church, Church of England, where he was also steeped in the Book of Common Prayer. (The rest of the area of Dorset was evangelical.) Timothy Hands in his lecture at the Thomas Hardy Conference on July 31, 1992, indicated the religious conflict of the times as well as underlining the strong influences of Christianity on Hardy during his formative years:

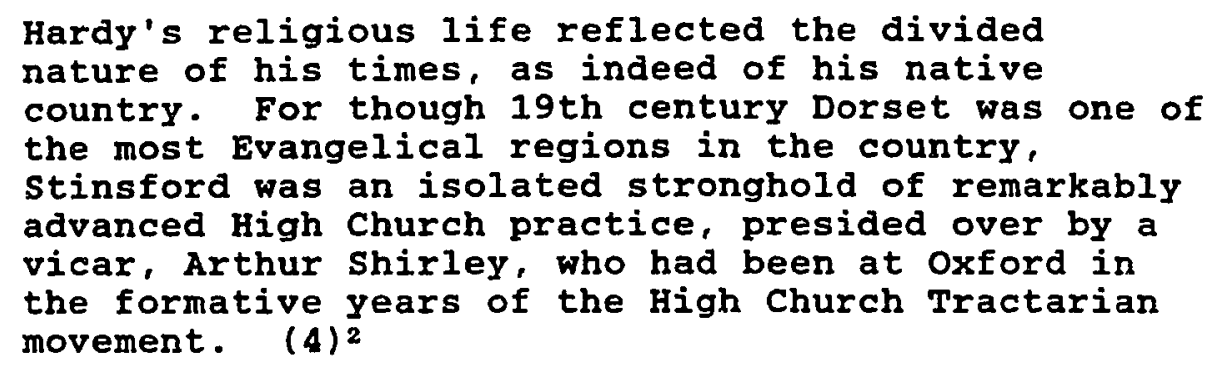
nature of his times, as indeed of his native country. For though 19 th century Dorset was one of the most Evangelical regions in the country, stinsford was an isolated stronghold of remarkably advanced High Church practice, presided over by a vicar, Arthur Shirley, who had been at oxford in the formative years of the High Church Tractarian movement. (4) ${ }^{2}$

There can be seen a change in Hardy from high to low church. Although he remained emotionally tied to the church he become sympathetic with the evangelicals, as is evident in Tess, a novel, according to Hands, that "reads like a parody of an evangelical tract. . . A parody of the Evangelical cautionary tale, Tess depicts not a young girl

\footnotetext{
2 Hands in his book, Thomas Hardy: Distracted Preacher? clarifies the distinction between the movements of High Church Tractarian, Low Church Evangelicals, and liberal Broad Church in the Church of England: "The High Church Tractarian or Oxford Movement stressed the antiquity or catholicity of the English Church, whilst the Low Church Evangelicals, despising ceremonial, placed considerable emphasis on the power of the revealed word. The liberal Broad Church, with a more latitudinarian theology, though agreeing precisely with neither party, hoped, forlornly to serve as the uniter of both" (1).
} 
saved by Evangelicalism, but a heroine destroyed by exponents of it" ("'A Bewildered Child and his Conjurors"" 7).

It seems somewhat contradictory that Hardy could place his heroine at the center of the conflict between high church orthodoxy and low church diverse doctrines. Hardy seemed to know a great deal about such sects as liberal broad church and low church evangelicals. He could not have scorned the high purpose of the evangelical alliance formed in 1846, which had members of churches from England, France, Germany, Ireland, Scotland, Switzerland and the United states. This alliance was one of the earliest expressions of a trend toward Church unity called the "ecumenical movement." Instead, Hardy used the tension between the Anglican and low church faiths all through Tess, with a heroine constantly asking to understand why her life seems to force her into positions contrary to accepted English mores and, by Anglican interpretations, dangerous to her own soul. None of the explanations of the clergy or those of Angel seem to make sense to her. Her demeanor at the end of her life suggests she has formed her own reconciliation between society's condemnation and her own internal sense of truth and rectitude.

In fact, the accumulation of internal tensions in Tess paces this novel, and when the rush to doom is over, the 
release of tension is so great that nothing much remains to be said and Angel and Liza-Lu depart the scene in mute accepting sorrow.

The influence of this early education in the scripture is evident in his early novel, Far from the Madding Crowd, which contains elements of the old Testament story of David and Bathsheba. Here, the male protagonist in Far From the Madding Crowd is Gabriel Oak, a shepherd like David. The biblical shepherd David is credited with the writing of the twenty-third psalm, which begins with invoking the importance of the concept of the shepherd in the lines, "The Lord is my shepherd." Hands points out in his book Thomas Hardy: Distracted Preacher? that:

Gabriel's Christian name is Hebrew for 'man of God,' and his occupation as a shepherd must have possessed religious as well as classical connotations for the victorian reader. 'The early church. . . took special delight in representation of Christ under this figure'. . . Harvey Brooks reminded his parishioners. (6364).

The image of Gabriel, the shepherd as man of God, quietly permeates Far from the Madding Crowd. As shepherd, he is one who cares for the helpless sheep who stray, protects them against all dangers, is always present to comfort, asks nothing for himself, is absolutely reliable and unswerving. He is also single-minded, strong in purpose, and if he suffers, it is done without complaint. 
He is a strange choice as hero. Gabriel has all these qualities and seemingly no great flaw, but he is not a source of drama. The reader sees him standing quietly, perhaps leaning on a staff, observing Bathsheba with all her attractions and making no comment on her sometimes tempestuous conduct. Instead, the drama in Far from the Madding Crowd seems to derive mainly from subplots. Troy and Fanny bring to the story flamboyant courting, strong physical attraction, passion, careless cruelty, injustice, conflict with social moral standards, and death and bitter sorrow. The flicking sword in the scene between Troy and Bathsheba, with its overtones of passion, masculine dominance, and danger, is the image perhaps most remembered from their love affair and one that motion picture director Roman Polanski used perhaps to excess in his screen version of Far from the Madding Crowd.

Boldwood brings fixed infatuation, instability, and extreme grief when rejected, to the plot. He kills Troy, lands in prison, eliminates himself as a contender for Bathsheba's hand, thus in the process eliminating Troy and leaving the field open for Gabriel. He also contrasts with Gabriel's essential strength in his sometimes gloomy, moody responses to setbacks in his plans.

By comparison with Troy, Gabriel is often merely a presence until all of Bathsheba's holdings are threatened as 
well as Bathsheba herself. As the storm develops in fury, Gabriel seems to grow in stature and become the natural, sane, controlling strength which averts disaster.

G. Glen wickens in the article, "Literature and Science: Hardy's Response to Mill, Huxley and Darwin," points out further that biblical imagery is prevalent in the novel:

Oak saves the blasted sheep with his "instrument of salvation" (192) and shears his flock in the great barn which "resembled a church with transepts" (195). "Here the shearers knelt" (196) and Bathsheba honors Oak, as nature's priest, "anointing him above his fellows" (203). The barn is a sacred place where nature is cultivated in "functional continuity" (195) with the past: "The defence and salvation of the body by daily bread is still a study, a religion, and a desire" (196). (Wickens 77)

Marjorie Garson in Hardy's Fables of Integrity connects the biblical story of Adam with weather imagery, which is a focus of this study, in Far from the Madding Crowd:

When his sheep are killed, Gabriel has a vision of nature as demonic which is evidently intended to be read as an epiphany and to signal a positive stage in his moral development. Gabriel's is a happy fall--his "loss gain." He eventually prospers because, like Adam, he has learned he has to work and to adjust his behavior to "weather" in the widest sense (it, is suggestive that the site of Gabriel's testing is called Weatherbury, since weather begins with Adam's fall. "Wetherbury" is the name of an ancient earthwork in Dorset. Wetherbury Castle.) The most important polarity in the novel is between man and nature, and only Gabriel, bowing to Adam's curse, can bridge the gap. (29)

Thus, Hardy's use of biblical materials in Far from the 
Madding Crowd was explicit and seems to proceed from still devout, orthodox, literal Christian thinking. In his Iibrary, however, is a range of works, some of which question or deny nineteenth-century Anglican beliefs and practices. Such a work as D.F. Strauss's Life of Christ (1835) contains a fairly standard biography but attributes a secular, mythical origin to the miraculous narrative of the Gospels. Among the works also were the great poems Paradise Lost (1667) and Paradise Regained (1671) with their astonishing realizations of Christ, the Devil, Heaven, and Hell born out of John Milton's desire to create a national epic. In the collection also were some of Milton's controversial tracts, notably The Doctrine and Discipline of Divorce, and the Areopagitica which argues what is now called "freedom of speech."

The inclusion of Milton's Doctrine and Discipline of Divorce in Hardy's library suggests that Hardy was keenly aware of the rise of eighteenth-century liberalism and its collisions with the reigning religious concepts concerning human conduct. That tract is presented in a totally historical, religious train of reasoning from Greek and Roman authorities down through Hebrew and Roman Catholic/Anglican views of the proper relationship of man and woman in marriage. The full title with its hectoring phrases such as "bondage of the canon law" and "bad 
consequences of abolishing, or condemning as sin that which the law allows" clearly indicates that Milton intends to destroy the strong stand of Anglicanism versus divorce. "This attack on the Canon Law of Anglicanism," which proclaimed marriage as indissoluble, Milton said was iniquitous, providing for the right of the body in marriage but nothing for the wrongs and grievance of the mind. Milton argues further that a loveless marriage is no marriage and that God "commands divorce" both in the law and through the prophets. Only the universal respect of the educated public for the scholarship of "the greatest of English religious poets" kept the educated public from seeing this argument as destructive to morals. Perhaps the poet's misery in his third marriage to a young girl who left her husband's sober home for the comforts and gaiety of the provincial life was well known and inclined the public to sympathy.

Hardy's library also included Milton's Areopagitica (1644), probably Milton's best known prose work because of the greatness of its cause and the eloquence of its rhetoric. A Speech to the Parliament of England, it commanded more interest than most of his other theological or political writings in its argument for "the liberty of unlicensed printing." Getting his Tess of the d'Urbervilles printed might well have been impossible under a system where 
novels might have to be "licensed." Today we still consider "freedom of speech" a highly important matter, in fact one of our most important "freedoms."

The second early influence on Hardy was that of his classical studies which gave Hardy a strong grasp of mythic explanations of the universe. Since Hardy was not educated in a public school, he did not automatically receive, as had Swinburne at Eton, the thorough classical training which, in the middle of the last century, was the main item of instruction in those schools. At the school Hardy attended Greek was not taught and Latin was an "extra." Hardy began to receive this extra at twelve or thereabouts, as Mrs. Hardy relates in Early Life (29).3

Although there is no further record of Hardy's classical studies during his school days, there is evidence of the depth of Hardy's study of the classics as a young man well before his writing of Far from the Madding Crowd. Apprenticed to an architect beginning in 1856, he became seriously interested in Latin studies. This is when he read the Aeneid, Horace, and Ovid; and took up Greek, "getting on with some books of the Iliad" (Rutland 21).

${ }^{3}$ We know that in addition to his extensive study of the Bible in English, he later read the Bible in Latin, and--at least the New Testament--in Greek. 
To Hardy's scholarly readings of Greek and Latin classics and his close knowledge of the Bible in various ancient languages can be attributed the way in which he easily blends religious lore, classical myth and medieval themes in his own writings. A blending of Christian and ancient classic imagery occurs in Far from the Madding Crowd, for example. Flowers planted on Fanny's grave in her honor are washed away by water pouring from a gargoyle high on stinsford church. In addition, the name "Troy" is that of the ancient city in Asia Minor also called "Ilium" famous in the legends of early Greece. These mixtures of classical and religious myths seem to exist in easy juxtaposition. Garson suggests another, possibly illusionary example of this coupling of religious and classical myths earlier in the novel when Troy does his sword exercise around Bathsheba making reference back to the old Testament and the story of Moses. "The symbolic function of Bathsheba as a figure is finally made startlingly clear in the strangely unselfconscious comparison between the 'liquid stream' released by Moses' rod and Bathsheba's 'stream of tears'" (Garson 39).

A volume of the Iliad which was inscribed "Thomas Hardy 1858" shows how thoroughly he studied the Iliad for years. Rutland found the text of Hardy's copy of the Iliad throughout is full of little notes in pencil; and the list 
inside the cover seems to be of his favorite passages which shows his interest in myth during this time.4

Although Hardy did not use these "favorite" myths in Far from the Madding Crowd, the novel displays his accumulated interest in myth. Garson points out how Hardy used his interest in the characteristics of mythic figures to present the duality of Bathsheba in Far from the Madding Crowd. Garson sees Bathsheba's association with Diana as her masculine side and Venus as her feminine side.

Bathsheba's boyish qualities--her horseback riding, for example, and her distrust of marriage--derive from the Diana side of her nature, so too do details usually associated with the image of the moon. Garson also buttresses his view of the feminine side of Bathsheba with figurative images of Venus.5 In these examples from Garson, we see the classical

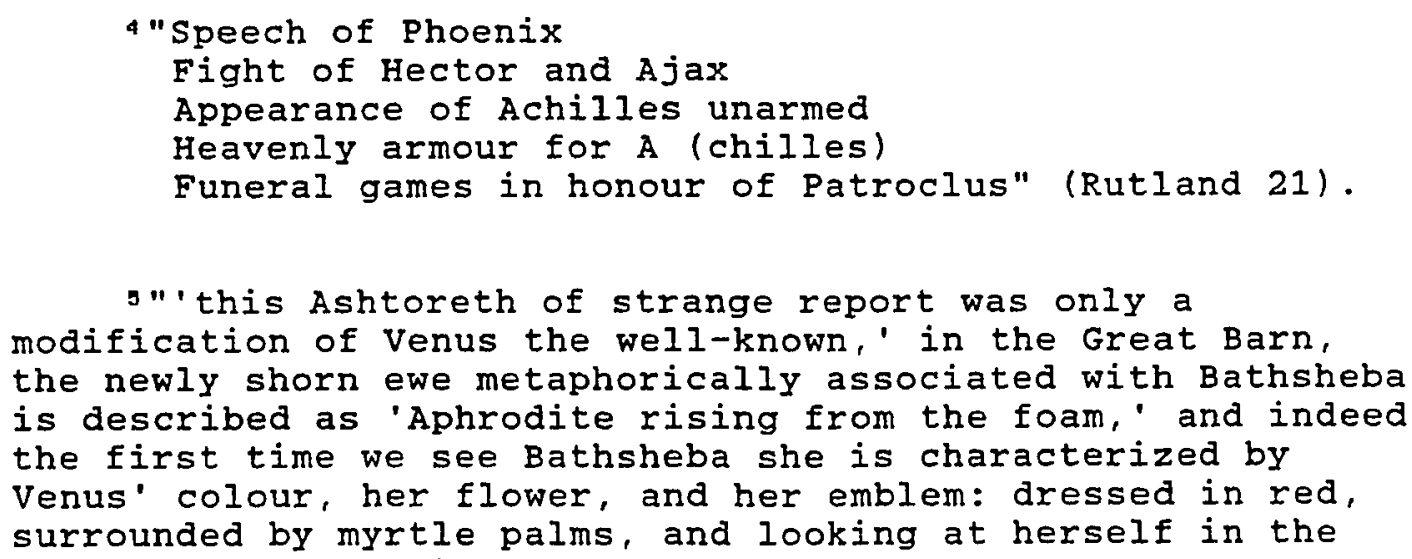


myth of Venus modified by the medieval and later interest in the mirror image.

The literary allusions in his writings, in the $1860 \mathrm{~s}$ throw light on Hardy's readings during the time. He read Virgil's Aeneid followed by Horace. In later years he read Catullus and Lucretius. After teaching himself Greek during the first two or three years of his apprenticeship, he began to dip into Attic drama as soon as he was able. In the preface to his translation of Oedipus Rex, Gilbert Murray writes that that play depicts human beings as the playthings of Gods strangely and incomprehensively malignant, whose ways there is no attempt to explain or justify. This fits in with the weather imagery in Far from the Madding Crowd as the weather imagery carries portents of malignancy or balm from the Gods, as will be shown in chapter two of this study. According to Rutland, some of the thinking that we associate with the philosophers of Hardy's time actually was partly derived from classical writers which Hardy also read: "the conception of the Immanent Will, besides what it owned to Herbert Spencer, J.S. Mill, Schopenhauer and others, may also have owed something to Aeschylus" (34). The influence of the Greeks such as Aeschylus and Sophocles confirmed the cast of Hardy's thought. Rutland says that "Hardy saw himself as the tragic poet acutely conscious of universal suffering, and yet deeply resenting the accusation of 
'pessimist' on the ground that 'if a way to the better there be, it exacts a full look at the worst,' and believing himself a 'meliorist'" (36). Hence, the reading of the Greeks influenced Hardy's thought in addition to the nineteenth-century writings of Schopenhauer and Von Hartmann.

This brings us to the second heading of analysis of the effect on Hardy of philosophic influences closer to his time in history than the ancients. These philosophers were to varying degrees responsible for Hardy's movement from mythic views of the world to more scientific ones. In a statement which includes biological scientists and philosophers together, Hardy said he held the same views as Darwin, Comte, Mill, Huxley, Spencer, Hume, and Schopenhauer. The philosophers and their associates can be divided into the philosophical schools of agnostics, pessimists and optimists.

\section{PHILOSOPHY: AGNOSTICISM}

The agnostics, which are also included with the freethinkers, were the first category of these philosophers who influenced Hardy's thinking. The word "agnostics" came into general use in the early 1870s. An "agnostic" was one who held that the ultimate cause (God) and the essential nature of things are unknown or unknowable or that human knowledge 
is limited to experience. It is said that the term was suggested by Thomas Huxley at a party held previous to the formation of the Metaphysical Society at Mr. James Knowle's house on Clapham Common one evening in 1869. Huxley took it from St. Paul's mention of the altar to the Unknown God.6 These free-thinkers were such men as A.C. Swinburne, J.S. Mill, Thomas Huxley, Matthew Arnold, Leslie Stephen, and Herbert Spencer. Swinburne's writings appealed to Hardy's emotions, whereas those of J.S. Mill influenced Hardy by their appeal to his intellect. ${ }^{7}$ why would this doctrine of the agnostic appeal to the English at this point in history? The answer lies in the realization that it was not only the severer doctrines of the Church which had lost their hold upon the intellect and conscience of Christian people, but the Church itself and the religion for which it stood that

6 This is the account of the word given in the oxford English Dictionary.

${ }^{7}$ Hardy was 25 or 26 when he was steeping himself in the writings of agnostics--to use the phrase coined by Huxley-who proved to his satisfaction that the omnipotence of a First Cause was incompatible with its goodness. In the light of these facts, it is easy to understand Tess with its famous ending:

Upon the cornice of the tower a tall staff was fixed. Their eyes were riveted on it. A few minutes after the hour had struck something moved slowly up the staff, and extended itself upon the breeze. It was a black flag. 'Justice' was done, and the President of the Immortals in Aeschylean phrase, had ended his sport with Tess. (489) 
had lost their hold upon a large section of the English public. The position is described by Matthew Arnold in the preface to Literature and Dogma. The assertion concerning a Great Primal Cause, which is unverifiable, must be replaced by that of "an enduring Power, not ourselves that makes for righteousness." But the possibility of the enduring ascendancy of this belief system Arnold calls as impossible to restore as the predominance of the feudal system or the belief in witches (Rutland 77).

Arnold was gentle compared to Leslie stephen in his attack on the Church. In "An Agnostic Apology," which appeared in June 1876 of Fortnightly Review (two years after the publication of Far from the Madding Crowd), Leslie stephen, talking of the theologians, says, "It is enough to say that they defined the nature of God Almighty with an accuracy from which modest naturalists would shrink in describing the genesis of the black beetle" (Rutland 78). Leslie stephen exercised no small influence over Hardy in the 1870s. Stephen's essays on questions of religion are mostly published in two volumes, Essays on Freethinking and Plain Speaking (1873) and An Agnostic Apology (1893). Although many writers on Hardy's philosophy ignore stephen, there is unmistakable evidence of stephen's influence on Hardy from Mrs. Hardy. On a visit to London in the winter of 1873 Hardy had made the personal acquaintance of Leslie 
Stephen, the man whose philosophy was to influence his own

for many years, indeed, more than that of any other

contemporaries (Early life 132).

Coming into contact with Leslie stephen about 1873 ,

Hardy was much influenced by his philosophy and also by his criticism. Hence, the thinking of this agnostic was one of the forces working on Hardy to move him away from religious imagery by the time of the publishing of Tess in the 1890s.

The general tone of stephen's rationalism can best be seen by a quotation from an article called "Are we Christians?" appearing in the Fortnightly Review for March 1873. In this he examined evidence of Christian attitude and conduct in England, and concluded that the reverence for the Bible and their observance of sunday are proof that Christianity was still alive in England.8

In June 1876 Leslie Stephen published an article entitled, "An Agnostic Apology," in which he contended that the position of the agnostic was the only one compatible with intellectual honesty. Of an attitude of mind savoring

\footnotetext{
8 "Our reverence for the Bible is, as Dr. Newman tells us, the strong point of Protestantism; and our observance of the sunday is the one fact which tells a foreigner that we have a religious faith. No one, whatever his opinions, should undervalue those beliefs, or, if they must so be called, superstitions. On English Sunday, with all its gloom and with all its drunkenness, is a proof that we do in fact worship something besides our stomachs" (Quoted in Rutland 80 ).
} 
distinctly of Leslie stephen there are many traces in Tess. Perhaps the clearest are to be found in the fourteenth and eighteenth chapters, both in connection with Ecclesiastics. Among other writers who influenced Hardy's thought after 1860, Gibbon was certainly one. Like many other agnostics, Hardy had made a study of the famous fifteenth and sixteenth chapters of the Decline and Fall. Gibbon's chapters on early Christianity were controversial because of his ironical approach. His point of view is best expressed in his observation that history is a record of "little more than the crimes, follies and misfortunes of mankind" (Reader's Encyclopedia 257).

\section{PHILOSOPHY : PESSIMISM}

Pessimism was the second school of philosophical thought which influenced Hardy. Pessimism was the name given to the doctrine of Schopenhauer, von Hartmann, and other earlier and later philosophers, that this world is the worst possible, or that everything tends to evil. He was reading von Hartmann and Schopenhauer in the 1880 s between the writing of Far from the Madding Crowd and Tess. Hardy owed a debt to schopenhauer as he did to Herbert spencer and J.S. Mill. There had been some awareness of schopenhauer in England during the 1870s but the first version of Die Welt als Wille und Vorstellung was published in three volumes in 
1883. Hardy bought this book, and the English version, The World of Will and Idea, was still in his library in 1938 when his wife auctioned his collection (Cox 196). In the area of his view of the Will, Hardy was influenced by German philosophers Kant, Schopenhauer, and von Hartmann in his development of the idea of the Immanent Will.

Some of Schopenhauer's ideas such as his views on death and suicide seem extreme and almost ridiculous today. Nevertheless, some aspects of Hardy's idea of Will do correspond with Schopenhauer's. Schopenhauer's The World as Will and Idea contains ideas in the chapter "will as the Thing in Itself" and "The will in Nature" which are particularly close to Hardy's.

Schopenhauer built on Rant's idea of the distinction between the phenomenal world--the world as it is experienced and rationally understood--and the noumenal world--or the world as it is, independent of the perceiver's rational apprehension of it. In the second volume of The World as Will and Idea, which treats the objectification of the Will, Schopenhauer defines Will, and explains his preference for the concept of will to that of Force as the underlying Principle of the Universe. In section 23, schopenhauer states:

The will as a thing in itself is quite different from its phenomenal appearance, and entirely free 
from all the forms of the phenomenal, into which it first passes when it manifests itself, and which therefore only concern its objectivity. (qtd. in Rutland 93-94)

Schopenhauer's conclusion on the subject of the will is this :

In fact, freedom from all aim, from all limits, belongs to the nature of the Will, which is an endless striving. . . . Eternal becoming, an endless flux, characterizes the revelation of the inner nature of the will. (gtd. in Rutland 95)

In calling the will "blind," Schopenhauer meant only that it has no further end than the perpetuation and proliferation of life itself; and life, as contrasted with living for something, he considered the essence of meaninglessness, or what he sometimes called "Vanity." Also the same drama, the same law, the same primordial will to live and to perpetuate life simply for its own sake, seemed to schopenhauer to be repeated in every species, an idea echoed in evolutionary theory. Schopenhauer goes on to extend his ideas to religion and the invention of gods. Schopenhauer echoed by Hardy from Far from the Madding crowd to Tess, a movement from mythic to scientific.9

\footnotetext{
9 "Men thus invent their gods, as just those beings who can overturn the verdict of nature and seize from the grave its victory. . . . If, Schopenhauer observed, men should ever become convinced of their mortality by the clear evidence of science and their own experience, their lively interest in religion would evaporate with that conviction" (Taylor 373).
} 
It is commonly supposed that the Doctrine of the unconscious Immanent will, which forms the great theme of Hardy's greatest work, owes a debt to the writings of Schopenhauer and von Hartmann; but there is a debt to Mill as well. In the second of the Essays on Religion, that on Theism, written between 1868 and 1870 (Mill's last important work), the third chapter deals with the Evidence of Theism and discusses the theory of Will as Prime Cause. Mill, who is of course combating the argument of those who use Will as synonymous with Personality, rejects this; but he makes a comment upon it which, in conjunction with the known facts of Hardy's attitude, is highly suggestive; Mill himself is dissenting from the proposition which he describes:

The assertion is that physical nature must have been produced by a will because nothing but will is known to us as having the power of originating the production of phenomena. . . That nothing can consciously produce Mind but Mind is selfevident, being involved in the meaning of the words; but that there cannot be unconscious production must not be assumed. (qtd. in Rutland 69)

Also among the pessimists who influenced Hardy by their ideas concerning the Immanent Will was von Hartmann whose ideas came under discussion in England in the later 1870s. Die Philosphie des Unbewusstes was translated into English by W.C. Copeland and published in 3 volumes in 1884 . Even if Hardy did not say so, there would be no doubt that 
he had read this work: especially that part of it which deals with the metaphysics of the Unconscious.

One phrase of von Hartmann may be regarded as the immediate origin of Hardy's metaphysics of the Immanent Will:

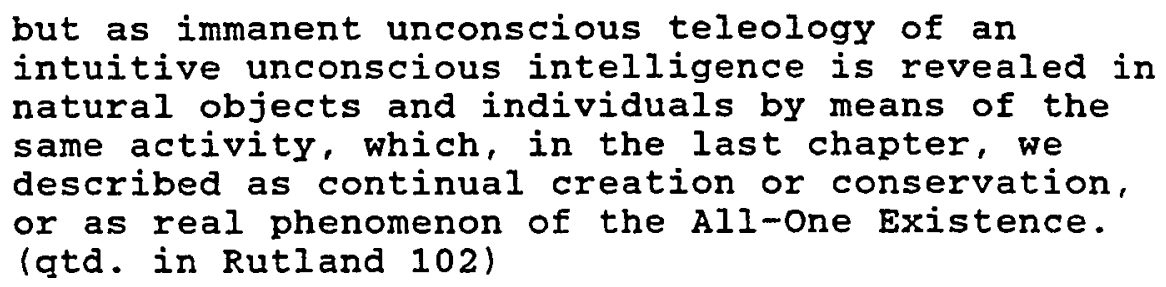

James Thomson's poem entitled "City of Dreadful Night," which appeared in the National Reformer (a periodical founded by a group of free-thinkers in 1860) underscored the belief that Pessimism was produced by the free-thinking crusaders of the mid-century, who had destroyed religion, and had given nothing in return but a deterministic nihilism.

In 1859 Edward Fitzgerald produced what was called a translation of the Rubaijat; but Hardy's works contain much that is typical of the pessimism of the later nineteenthcentury in England, anticipating Thomson by twenty years. The first edition was not successful; however, by the $1880 \mathrm{~s}$ when it had reached four editions, many had come to believe with Hardy, that "nothing is made for man." And Fitzgerald bears the same burden as Thomson:

And that inverted bowl we call the sky, Whereunder cooped we crawling live and die, 
Lift not thy hands to it for help--for it Rolls impotently on, as thou or I. (qtd. in Rutland 88)

Leopardi was another pessimist with whose work Hardy was acquainted and a translation into French of Leopardi by F.A. Aulard published in Paris in 1880, was in Hardy's library. Leopardi was one of the greatest pessimistic poets of the nineteenth century. A reference to influential pessimists, Schopenhauer and Leopardi, occurs in Chapter XXV of Tess.

[old Mr. Clare's] creed of determinism was such that it almost amounted to a vice, and quite amounted, on its negative side, to a renunciative philosophy which had cousinship with that of Schopenhauer and Leopardi. (218)

The obituary of Hardy in The Times for January 12, 1928 comments on the English writer's debt to Von Hartmann and Schopenhauer. 10

PHILOSOPHY : OPTIMISM

Optimism was the third school of philosophic thought which corresponded for Hardy with a belief in scientific advance. Optimism, or more appropriately the meliorism

10 "He had embraced with sad-eyed acquiescence the metaphysical doctrine of Schopenhauer and Von Hartmann, that the life of man is the product and the wind-driven derelict of a blind will, immanent in the Universe, but careless, because unconscious, of human happiness or progress" (Quoted in Hands, "A Bewildered Child and His Conjuror's"" 21). 
doctrine as it is called, is expressed by winwood Reade in The Martyrdom of Man:

A time will come when science will transform [the world]. . . Disease will be extirpated; the causes of decay will be removed; immortality will be invented. Man will then be perfect.11

As noted by Mrs. Hardy from Hardy's diary for 1880, Hardy became acquainted with Auguste Comte's writing during the 1870s:

If Comte had introduced Christ among the worthies in his calendar, it would have made Positivism tolerable to thousands who, from position, family connection or early education, now decry what in their heart of hearts they hold to contain the germs of a true system. (Early Life 189)

It would have been strange had Hardy not read comte for, from the time when the writings of the French philosopher became available in English about the middle of the century, "Positivism" had became a very popular word; although it is doubtful whether all those who so lightly bandied it about had ever looked into comte's work. To such an extent did this word Positivism enter into the popular vocabulary, that it caused great annoyance to other philosophers to whom it was applied indiscriminately. The essays of Herbert Spencer contain a vigorous protest against this affliction; and Huxley made an attack on Positivism in

11 Cited by Webb, My Apprenticeship (Cambridge: Press Syndicate of the $U$ of Cambridge, 1979) 114. 
an essay "The Scientific Aspects of Positivism in Lay Sermons" (1870).

Rutland further suggests it is undeniable that the philosophy of Auguste Comte had no small influence in England in the latter half of the nineteenth century. George Eliot was a student of Comte; and even many of those who were not students were affected by ideas in the air which derived from him. For example, Swinburne, whom no one has yet accused of being a Comtist, was voicing the essential doctrine of the 'Philosophie positive' when he wrote in Songs Before Sunrise: "Not each man of all men is God, but God is the fruit of the whole. Comte did, in fact, attempt to devise an immanentist religion in which a transcendent God was displaced by Humanity, conceived as a single entity and advancing towards perfection," says Rutland (84). Comte shows this in his statement of his philosophy :

\footnotetext{
A deeper study of the great universal order reveals to us at length the ruling power within it of the true Great Being, whose destiny it is to bring that order continually to perfection by constantly conforming to its law. (qtd. in Rutland 84)

In Tess, Angel, argues with his father, reeling off Positivist clichés. Religion must be reconstructed: humanity, not God, should be the focus of reverence and attention. No wonder that Hardy's friend Frederic Harrison,
} 
leader of the English Positivists, and therefore perhaps not the most impartial of critics, should tell the author that "to me it reads like a Positivist's allegory or sermon."12

Rutland says,

The lengths to which Comte developed his Religion of Humanity caused Huxley to describe it as "ultramontane Christianity without Christ." This doctrine cannot have been very congenial to Hardy, who never had any such bent towards sociological idealism as had Shelley or Swinburne. Hardy naturally read comte: but it is doubtful whether he took much from him. In many important respects, the ideas which comte entertained for the emergence of a better order of things were diametrically opposed to those of Hardy. (84-85)

As compared with Comte, Hardy felt that there was the possibility of betterment (melioration) in man's situation

but not much chance of perfection.

Hardy obviously took an interest in various

philosophers with their seemingly opposing views such as the Pessimists and the Optimists. On the last day of 1901 Hardy wrote in his diary:

After reading various philosophic systems, and being struck with their contradictions and futilities. I have come to this: Let every man make a philosophy for himself out of his own experience. He will not be able to escape using terms and phraseology from earlier philosophers, but let him avoid adapting their theories if he values his own mental life. Let him remember the fate of Coleridge, and save years of labour by working out his own views as given him by his surroundings. (Later Years of Thomas Hardy 1892-

\footnotetext{
Collection.

12 Letter to Hardy, 29 December 1891, Hardy Memorial
} 
$\underline{1928} 911$

\section{SCIENCE}

Instead of being a period of stagnation, the midVictorian years were in fact a time that produced a crisis in intellectual life brought on by the sciences. The twentieth year of Hardy's life produced two events which are landmarks. The publication of two books brought a rapid change in our cultural history. The first edition of Charles Darwin's on the oriqin of Species appeared on November 24,1859 , and was sold out on the day of publication. The second edition became available in January 1860. In 1860 there also appeared a volume entitled Essays and Reviews. What must have impressed Hardy even more than the conclusions in Essays and Reviews was the method, which was imported from science, and was at that date new to theology. The importance of the scientific method was stated by Beatrice Webb in her book My Apprenticeship: "The belief in the science and the scientific method. . was certainly the most salient element of the mid-victorian Time-Spirit" (142) .

Hands points out that Hardy was most influenced by the scientific advances of Darwin and Huxley, particularly in 
the biological sciences.13 Influence of the ideas of evolution on the whole of English thought in the later nineteenth century came predominantly from the theory implied in Darwin's epoch-making book, on the origin of Species. The famous book, which became the gospel of so many in Hardy's youth, does not itself contain any philosophical speculation. It is a strict work of science, the contents of which may be concisely described in one sentence from the famous third chapter, "The struggle for Existence": "I should infer from analogy," wrote Darwin, "that probably all the organic beings which have ever lived on this earth have descended from some one primordial form, into, which life was first breathed."

Darwin discusses his idea of the Struggle for Existence in these lines from on the origin of species:

We forget that the birds which are idly singing round us mostly live on insects or seeds, and are thus constantly destroying life; or we forget how largely these songsters, or their eggs, or their nestlings, are destroyed by birds or beasts of prey. (116)

13 "Hardy's contact with scientific thought of the 19 th century, by which is meant principally geological and more particularly evolutionary studies, was of course non specialized, but so too in a way were those studies themselves, modern works of science being then, as they are not now, generally accessible to the general reader. The two principal men of the scientific movement were, for Hardy, Darwin and Huxley, the one formidable as an amasser and original interpreter of evidence, and the other a lecturer and polemicist of exceptional ability" (Hands, "A Bewildered Child and his Conjurors'" 8). 
This suggestion that life is mindless and cruel runs counter to the idea in scripture of an infallible, allpowerful Authority. Now, however, evolution enunciated a principle throughout the universe which assumed the existence of an intelligent Power capable of setting the process in motion but not constantly intervening. Such an impersonal view of creation as this forms a world out of nothing and makes of man a species which is in process, not a special species at the apex of some hierarchy. The idea that religion requires externally imposed powers, such as God, corroborates mythic elements; whereas, the Immanent Will is from within, like the germination of a seed, and is therefore without mythic implications.

Another German thinker was Ernest Haeckel (1834-1919) who was primarily a scientist, and was, indeed, the most distinguished German zoologist of his generation. In the introduction to The Descent of Man in 1871, Darwin wrote of Haeckel's Naturliche Schopfungsgeschichte (translates into English as The History of Creation): "If this work had appeared before my essay had been written, I should probably never have completed it" (3).14

${ }^{14}$ Freedom in Science and Teaching, which was largely concerned with a controversy over Evolution in the German scientific world, appeared in 1879 with a prefatory note by Huxley. The Pedigree of Man and other Essays, 1883 , were so largely scientific as to be unlikely to appeal to a layman like Hardy. But Hardy would have read Haeckel's Riddle of the Universe, however, because it was a popular exposition, 
The speculative writer whose name is especially associated with the doctrine of the immanence of the Primal Cause as a means of reconciling religion and science, is Herbert Spencer (1820-1903). Spencer who was a friend of Darwin and Huxley and who coined the phrase "survival of the fittest," had already published four works by 1860 . Thomas Henry Huxley (1825-1895) was an active champion of the theory of Darwin. While Darwin remained in comparative seclusion, Huxley set out to secure fair public hearing for the new theories. It was not until the 1870 s that Hardy met Huxley face to face. Then, says Mrs. Hardy, "For Huxley he had a liking which grew with the knowledge of him" (Early life 159). Huxley has the following view of the interference of religion in the scientific community:

The myths of paganism are as dead as Osiris and Zeus, and the man who should revive them, in opposition to the knowledge of our time, would be justly laughed to scorn but the coeval imaginations current among the rude inhabitants of Palestine, recorded by writers whose very name and age are admitted by every scholar to be unknown, have unfortunately not yet shared their fate, but, even at this day, are regarded by nine-tenths of the civilized

in rather provocative language, of an extreme form of materialism or the doctrine that physical well-being and possessions constitute the highest good. Haeckel claims that science has conclusively established that there is no such thing as a soul; that all deduction from the hypothesis of soul, including, of course, all religion, are mere delusions and that the religion of the twentieth century will be "scientific monism" or the theory that reality is a unified whole. 
world as the authoritative standard of fact and the criterion of the justice of scientific conclusion in all that relates to the origin of things, and among them, of species. (qtd. in Rutland 59)

Huxley had to come up against Samuel wilberforce, Bishop of Oxford, because Huxley was more outspoken than Darwin on the issues of evolution. Bishop Wilberforce, a creationist, relished opportunities to challenge Huxley and discredit him on evolution. Bishop Wilberforce attack on Huxley at a meeting in June, 1860, of the British Association for the Advancement of Science, where Huxley was also present, is one such example. He confronted Huxley, and with mock politeness "begged to know, was it through his grandfather or grandmother that he claimed his descent from a monkey?" (Irvine 5). Huxley replied, with equal sarcasm, that "he would not be ashamed to have a monkey for his ancestor; but he would be 'ashamed to be connected with a man who used great gifts to obscure the truth" (Irvine 6). Although the biological sciences had the greatest influence on Hardy, there is evidence that Hardy was influenced by other scientific thought such as astronomy and physics. Hardy's awareness of astronomy can be seen in Tess. There is a famous passage in the fourth chapter of Tess, in which Tess's little brother asks her if the stars are worlds: and in which the girl is made to reply that they 
are worlds, "like apples on the stubbard tree, and that we live on a blighted one" (69-70).

In the fourth chapter of another of Hardy's novel, Two on a Tower, he displays both a knowledge of the idea that suns burn out and consciousness of physics and of the second law of thermodynamics called "entropy."1s The theory of the universe upon which this passage is based is from the first chapter from James Jeans's The Mysterious Universe (15). In a chapter on the "Philosophy of science, 18501910," Alexander says that "It is striking that the scientists of the period who were interested in the philosophy of science were mainly physicists" (420). On the continent they were names like Ernst Mach, Heinrich Rudolf Hertz, Jules Henri Poincaré, and Pierre Maurice Marie Duhen. In England the names of Michael Faraday and Lord Kelvin were prominent.

15 "And to add a new weirdness to what the sky possesses in its size and formlessness, there is involved the quality of decay. For all the wonder of these everlasting stars, eternal spheres, and what not, they are not everlasting, they are not eternal; they burn out like candles. You see that dying one is in the body of the great Bear? Two centuries ago it was as bright as the others. The senses may become terrified by plunging among them as they are, but there is a pitifulness even in their glory. Imagine them all extinguished, and your mind feeling its way through a heaven of total darkness, occasionally striking against the black invisible cinders of those stars" (Hardy, Two on a Tower 34). 
These later novels of Hardy show the influence of the theories of thermodynamics which deals with the transference of energy and is a branch of science developed in the midnineteenth century. It is important to look more exactly into the theory of thermodynamics because it was being incorporated into the science fiction genre of such writers as H.G. Wells as well as into the realistic writing of Hardy. In 1847 Hermann Helmholtz proposed a law of "the conservation of living force," later called "the conservation of energy." The first law of thermodynamics states that energy is neither gained nor lost in operation, only transformed into some equivalent form. The energy of the whole system remains constant.

The second law of thermodynamics proclaims the ultimate exhaustion of useful energy. This will bring about the "heat death of the universe," the end of organic life through irreversible physical processes. It is sometimes expressed through the concept of "entropy." "Time's arrow has a definite direction in thermodynamical terms" (Chapple 46). Darwin about 1876 called this "the view now held by most physicists namely that the sun with all the planets will in time grow too cold for life, unless indeed some great body dashes into the sun and gives it fresh life" (Charles Darwin. Thomas Henry Huxley: Autobiographies 53). 
Knowing that physics played an important part in the philosophy of science, Peter Widdowson's suggestion in his book, Tess of the d'urbervilles, that there is a link between Tess and physics seems plausible. Although Widdowson is not commenting on Hardy's training in physics, the following passage does show how Hardy's later novel has moved to a way of "seeing" that can be described in terms from the science of physics. He makes reference to the importance of his strategy in viewing Tess in terms from physics when he says, "second, and for my purposes here more significant . . physics . . means the measure of a turning effect (as in 'the moment of a force')" (14-15). Physics deals with the concepts of space, time, mass, and force. Widdowsom sees Tess, a pure woman, as a focal point, a moment of force, around which men like Angel and Alex rotate. He goes on to say,

If we think for a (dare I say) moment of the effect of a turning vision--in the most literal sense--then we must conceive of a 'seeing' which moves round its object (consider astronauts observing Earth from their circulating spacecraft), and which can theoretically move around it through 360 degrees in any direction. (15)

Tess is like the earth from which men see a different person from their different perspectives, or in Widdowson's words, "one can see both profiles of a face simultaneously in Cubist portraits, or a violin dismantled with all its planes 
simultaneously displayed on the two-dimensional picturesurface of a modernist still-life" (16).

From the passage of Two on a Tower quoted above, it is evident that Hardy was aware of the thermodynamic theory that the sun was using up fuel. Tess indicates a further awareness of the vital role the sun plays in the life cycle. Common knowledge of the time was that without the sun there is no life. A final scene in Tess occurs at Stonehenge which is associated with the sun. Stonehenge's ancient significance for primitive science is continually being investigated. However, we do know that by moving a marker stone around an outer circle of holes once a year, priests or astrologers could calculate suitable times for crop planting, practice divination and predict weather cycles. The sun of stonehenge at the end of the novel contrasts with the blackness of the imagery of the black cloak, and the black flag at the execution.

Some hours before Hardy died, he asked his wife to read to him a certain verse from Fitzgerald's Omar Khayyam; and she read:

o Thou who man of baser earth didst make, And even with Paradise devise the snake For all the sin wherewith the face of man Is blackened, man's forgiveness give - and take. (qtd. in Rutland 108)

Hardy's deathbed request shows a still-profound interest in the testing of Christian beliefs, especially "the first 
fall." To one who thinks of the nineteenth-century Victorian frame of mind as predominantly Christian, the questioning of God's judgment in endowing the Garden of Eden with a snake to connive with Adam and Eve in defying the Supreme Being's edict not to eat the apples may seem close to heresy.

But Hardy also knew of his own contemporaries' movement to independence and doubt of established systems of belief. The dearly-beloved nineteenth-century poet-laureate Wordsworth expressed his grief over the loss of Lucy in lines so desolate and devoid of any of the great christian promises of an afterlife that they grate on the reader's senses :

No motion has she now, no force: She neither sees nor hears, Rolled round in earth's diurnal course with rocks, and stones, and trees.

There can be no solace here for the sensory affects but one can perhaps find comfort in an intellectual view that Lucy has become a part of nature. Additionally, Coleridge's great fable of sin and guilt, The Rime of the Ancient Marinex, resolves itself into permanent wandering as punishment to teach love and reverence for all of God's creatures. But significantly, it makes no mention whatever to the wanderer of blissful eternity in Abraham's bosom. Hardy's consciousness of the thought and scientific 
probings of his own time caused him to modify his early Christian view toward an agnostic position: he could not be sure of Christianity as inspired truth. He questioned the old tenets of Christian belief; and his poems sometimes have a format of a human being questioning God in a cemetery. However, he seems never to have eschewed Christian ethics (if reasonably applied), the life and example of Christ, the efficacy of religious sacraments of the Anglican church, the beauty of the rituals, and the like. Ronald Blythe, critic and writer, in his Introduction to the 1978 Penguin edition of Far from the Madding Crowd, speaks of the permanent effect on Hardy's sensibilities of "The Church of England, the religion which Hardy gave up but from which he never emotionally escaped." As Blythe elaborates:

It [Anglicanism] permeates the novel with its sunset glow, a faith on its last legs, its meaning tottering in the mouth of a labourer. Hardy is perhaps less emancipated from rural Anglicanism than from any other aspect of his background, actual belief apart. Weatherbury echoes with its moral and aesthetic resonance: it remains the ultimate language for the acceptance of things. But creeping into it with a comfortless and destructive force is his recognition of there being no everlasting arms to check the fall, whether of man or sparrow. These Christian and post-Christian attitudes, however, never really cloud a countryside where so many classical rural values prevail. This village is as much the territory of Hardy's readings in classical mythology as his boyhood involvement in church services. (35) 
Even more so does Tess show the depth of Hardy's questioning of Christian theology. In this novel are two Christian spokesmen: Angel's father as minister-interpreter of Christian truths, and Angel as Christian moralist. The attempts to explain Christianity to Tess, even to each other, seem futile, even laughable, while the "fallen woman Tess" seems ever more isolated in ignorance and despair. Hardy's calling Tess "A Pure Woman," in a subtitle which he attached just before publication of the novel, seemed almost bravado. He once complained that poetry could carry explicit criticisms of belief without eliciting much readercomment, but let the same thoughts be embodied in plot and characters of his novels and the writer would be besieged by angry readers. Proof of Hardy's response to this criticism of his novels was his decision, after the public's reaction to Jude the Obscure, to drop the novel and concentrate on poetry.

In the 1880 s Hardy was so involved in the scientific/religious questions of his day that his views on conflicts were sometimes sought by thinkers of various disciplines and persuasions and importance. The "Autobiography" recounts such an exchange among Hardy Dr. Gosart (theologian) and Sir Leslie Stephen.16

\footnotetext{
${ }^{16}$ Florence Hardy's biography of Thomas Hardy is considered by Hardy scholars to be almost autobiographical in its faithful recording of Thomas Hardy's life and
} 
Thus the questioning of a twelfth-century Eastern poet of God's intentions toward Man when he created the snake must have interested Hardy considerably. The Tentmaker's thoughts are cast in the form of an invocation,

It acknowledges a Supreme One who created Man and Eden--and the creation, also, deliberately of a Snake who was to bring Man down. God, if you will forgive me for my numerous sins against you, I will forgive you for your supreme sin against me when you tricked Man into disobedience of your will.

The tone of voice (possibly more traceable, of course, to Fitzgerald the improver-translator of the Rubaiyat than to Khayyam) sounds unlike a pious nineteenth-century Christian; in fact, it sounds more like the young tenor in Leonard Bernstein's modern Mass when he sings "I believe in God, if he believes in Me."

It seems entirely possible that Hardy, before his death, not only asked to hear Omar Khayyam's logical interpretation of the mutual guilt of God as the creator and man as the created, but that he may have referred to this verse from time to time in his active life because the poetry expressed something of his own quandary in reconciling current adversarial positions between science and religion.

Upon Hardy's death, his body was buried in Poet's

thoughts. 
Corner at Westminster Abbey, and his heart buried at Stinsford Church in Dorset County where he attended church as a boy.17 The symbolism of this reinforces a feeling that logic does not explain everything. In Hardy's life many sense he remained a Christian; however, in his mind and writings he found it necessary to question theology as he adopted the ideas that were being advanced by science. For the ideas of his time, then, Hardy acquainted himself with the works of Darwin, Huxley, Spencer, Comte, Mill, schopenhauer and others. Cataloging by subject this chapter has presented these influences and associated intellectual thought as mythic, philosophical and scientific. The succeeding chapters will show by focusing on the texts of Far from the Madding crowd and Tess how these earlier mythic and related religious images in the early novel Far from the Mading crowd in the area of nature, particularly in the weather imagery, transform into more scientific imagery in the later novel Tess.

\footnotetext{
${ }^{17}$ Hardy wanted to be buried in the grave of his first wife. However, in Thomas Hardy's Notebooks, Sir Sydney Cockerell is quoted as addressing the issue that Hardy knew he might be regarded as a national literary figure by the English: "He was far too humble a man to conceive of such a thing [a burial in Westminster Abbey] as at all likely. But as one of his executors I had put the matter before him, and in the directions he gave for his burial at stinsford, as well as in the provisional inscription that he designed for his tombstone, he was careful to leave a loophole for a possible alternative" (119).
} 
CHAPTER II

Far from the Madding crowd:

The strong Element of Myth and

Conventional Thinking about Nature

In Far from the Madding Crowd published in 1874, Hardy has reached a high point in his use of biblical, mythical, Hebraic, Hellenistic/pastoral, Romantic/Gothic and Wessex materials gleaned from his entire background. Imbued not only with the beauty of mythical images, Hardy also knew the utility of these images--to sharpen the pictures, to amplify plot or incident to suggest future happenings and the trend of character development, to set the mood or tone of the situation, and to release the reader's own imaginative perceptions by these analogies. In Far From the Madding Crowd Hardy leaned heavily on specific Bible references and Christian theology as well.

F. B. Pinion, in his chapter "Hardy and Myth," offers a definition of myth which encompasses ancient Greek and Roman mythology as well as modern Christian theology: "I assume that myths are religious in origin, and relate to gods or similar personalized powers, and nature, and that, even though their narrative features are fictitious, they can be 
used imaginatively by virtue of their original significance to reinforce or symbolize aspects of life" (103).

Considering the wealth of Hardy's literary knowledge, it is natural that this early novel Far From the Madding Crowd brims over with biblical references, classical lore and Hellenistic pastoral images. The settings are all Wessex, good solid English places, villages and farms which can immediately also by the use of imagery call up the isles of Greece or Attica or lands of the Bible or any country setting, while sheep and shepherds are biblical in reference without even the need for a simile.

Other image-assisted characters include Bathsheba, Troy, and Weatherbury (English kingdom of the Middle Ages) as Hands suggests:

The wealth of biblical proper nouns--Bathsheba, Cainy, Jacob, Joseph, Laban, Levi--makes the reader sensitive to the biblical parallels which underlie events. Bathsheba's name is also that of David's wife, and the singular scene in which Oak glimpses Bathsheba riding bareback is perhaps intended to recall David's poetic sight of his future spouse bathing by moonlight. (46)

Such imagery through names allows for the incorporation of great subtlety. "Troy" may suggest an embattled character doomed to destruction. In fact, he is a self-serving, arrogant military man at story's beginning and a penitent despoiler of Fanny at its end.

In such a torrent of emotion, steadfastness becomes a rare quality. It may be Gabriel Oak's chief virtue, and he 
triumphs. Boldwood has it to some extent but he is ravaged by the pain of unrequited love. Troy may somewhere, somehow achieve a smattering of steadfastness through penitence.

Bathsheba is enthroned above the turmoil.

How does Hardy build a unified novel out of this maelstrom? Answering this question provides an opportunity to observe where and how Hardy uses his tools of imagery and with such facility as to offset chaos, thus providing a unified whole.

Although the variety of images is great and they intermingle in the same passage, several types of images emerge and specific identifications and classifications are possible. Some images bear on the sights and sounds of the setting, suggest the character of individuals, establish the tone and trend of action, the feelings of people, emotional overtones from nature, animals, and plants, and the power of quiescent or raging features of Nature whose "spokesperson" is the weather.

The images will be indexed broadly by their sources: biblical/classical, Hellenistic/pastoral, Romantic/Gothic, and Wessex/weather.

\section{BIBLICAL/CLASSICAL IMAGES}

Biblical images abound in Far from the Madding Crowd. Already noted is that names alone may call up instant images. We know that Gabriel oak from the very beginning 
will be our hero. The image of "Gabriel" has the beauty, kindness and fortitude of the angel but also the added strength and dignity of being rooted in the soil as a magnificent oak tree. Immediately, the mixture of the Bible and images from nature form a simple yet grand picture of our hero.

For example, the hero is described immediately in the second paragraph: "His Christian name was Gabriel . . a man whose moral colour was a kind of pepper and salt mixture" (51). A description of Gabriel follows with mention of his "low-crowned felt hat," "ordinary leather leggings" (51), and other realistic details. Hardy offers no learned discourse about why Oak does not resemble Hector or Achilles or speculation about whether the man of the future might not more reasonably resemble the non-ideal but more worthy Oak. Hardy is secure in his selection of biblical and nature images of his hero.

Hardy uses a reference to the old Testament early in the novel to describe Gabriel's hut: "The image as a whole was that of a small Noah's Ark on a small Ararat, 18 allowing the traditionary outlines and general form of the Ark which are followed by toy-makers" (59). This description has

${ }^{2}{ }^{8}$ Mount Ararat is the hill on which Noah's Ark rested after the flood. This reference gives the feeling that Gabriel has weathered a storm before and will be a survivor for future physical storms as well as psychological storms of passion. 
later significance as Gabriel proves to be, of the three suitors of Bathsheba, the one best suited to survive the flood of passion in loving Bathsheba as manifested by his ability to survive nature's storms as well. Besides the specific religious references there are also large religious themes such as the Garden of Eden and Noah's Ark running throughout the novel. Hands in his book, Thomas Hardy: Distracted Preacher?, points out:

Biblical allusion everywhere makes continuity of tradition apparent. The attempt to parallel the contemporary fictional community and the ancient biblical world is calculated and sustained in Hardy's fiction as early as Far from the Madding Crowd, and perhaps is rarely of such importance as in this novel. Poorgrass may be forgiven for believing that he 'ought to have lived in Genesis by rights,' for Far from the Madding Crowd contains no fewer than twenty-one allusions to Genesis and Exodus. At times, Hardy removes the Weatherbury community so far from the madding crowd that it almost appears to be located in the world of the Pentateuch: 'we fokes in the congregation fell all over like the children of Israel,' as Cainy Ball somewhat justifiably remarks. (46)

Besides the most striking association of Bathsheba with the biblical story of David, other scriptural parallels are made explicit:

Boldwood's wait for Bathsheba is twice compared to that of Jacob for Rachel, and Oak dismissed by Bathsheba is likened to Moses leaving the presence of the Pharaoh, a comparison not without its relevance, for in both cases a subsequent disaster to the possessions of the dismisser is only alleviated on the return of the dismissed. In short, the biblical parallels in Far from the Madding Crowd are so widespread that Hardy, as if he were'some holy man living in the times of King Noah,' seems to have suffered from the multiplying eye which so affected Joseph Poorgrass that it 
caused him to see two of every sort. The suggestion of a stable community, strengthened by its links with a distant past, and as yet untouched by the strange disease of modern life, is greatly enhanced by such allusions. (Hands 46)

Classical imagery is also used to call up images from antiquity. As with biblical imagery, there are specific references to certain Gods, as well as an overall vastness and olympian nature which bespeaks the classic influence in Far from the Madding crowd. An example of this specific classical image is employed when Gabriel is searching for his lost ewes and lambs. Hardy uses a simile from a classic situation. He writes without elaboration that Oak "called again: the valleys and furthest hills resounded as when the sailors invoked the last Hylas on the Mysian shore, but no sheep" (85-86).

Another specific reference to myth appears early in the novel when Bathsheba is also associated with the goddess Venus who represents day, and the scene is one of good weather. Earlier in the novel scenes with their explicit depictions of myth will be sunlit; whereas, later in the novel scenes of threatening weather will develop such as the major storm scene. "It was a fine, morning, and the sun lighted up to a scarlet glow the crimson jacket she wore, and painted a soft lustre upon her bright face and dark hair" (54). Nights are clear and the sky replete with classical names and visions as the constellations associated 
with the night:

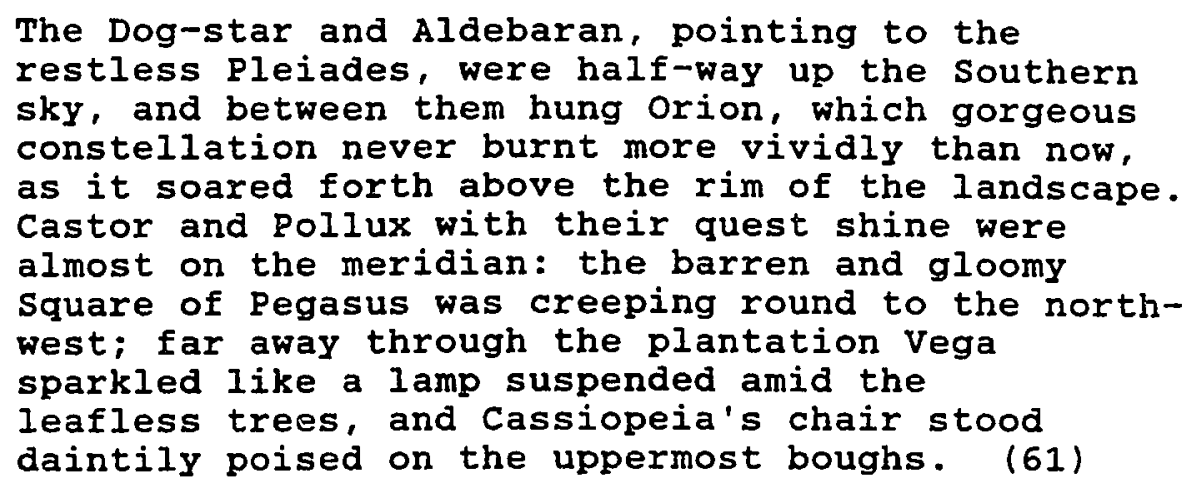

Midnights are "clear" but unmistakably touched by glamorous images of Greek purity such as "a panoramic glide of the stars past earthly objects" (58).

The presence of the Olympic vastness can be seen in mythic themes such as the Golden Age of the mythic pastoral, and Jupiter's wrath during the Golden Age running throughout the novel which produce a continued mythic connotation.

The passion of Troy and Fanny, as Lewis Horne suggests, involves two myths, one of chaos and one of charity, both of which characterize the romantic dilemma of Fanny and Troy. Chaos awaits the word, or as in a second creation myth recounted by Hesiod, Chaos awaits Love. In the lines "snow lining the heavens and that encrusting the earth would soon unite into one mass without any intervening stratum of air at alI" (135), Horne indicates that the selection of words by Hardy reminds one of "the union of Earth and Heaven, after Earth and Love had themselves created Heaven as an abode for the gods" (46). 
Far from the Madding Crowd has a vastness associated with Greek mythology. In fact, when Gabriel arrives at Bathsheba's farm there is a comparison of her to an Olympian god against the setting of an Olympian farm. When Oak and Bathsheba are reunited on her farm where she is the proprietor, then Hardy says of her:

But perhaps her air was the inevitable result of the social rise which had advanced her from a cottage to a large house and fields. The case is not unexampled in high places. When, in the writings of the later poets, Jove and his family are found to have moved from their cramped quarters on the peak of olympus into the wide sky above it, their words show a proportionate increase of arrogance and reserve.19 (131)

The mythic Golden Age has obvious parallels to the Garden of Eden as well. Gabriel Oak represents this world for Bathsheba. It was a time before seasons and rough weather. Perpetual spring reigned, flowers sprang up without seed, the rivers flowed with milk and wine, and yellow honey distilled from the oaks. Then proceeded the successively inferior ages of Silver, Brazen, and Iron. During the Iron Age there was warring with weapons. Troy's name represents a classic tale of a city of defeat while his sword-play represents his warring nature. Jupiter became angry during the Iron Age and summoned up the gods of

${ }^{19}$ Homer and the early Greek poets gave the top of Mount Olympus as the home of the gods because it was believed that its peak touched the sky. Later, when the superior height of the visible sky, 'the heavens,' was recognized, this became the divine abode. 
storms, the South wind and Neptune, to disturb the earth and destroy the current inhabitants so that he could provide a new race. The storm also laid the crops low with torrents of rain, and the year's husbandry was lost. This mythological storm has a parallel in the novel when Troy denies the onset of the storm during his dissipation in the barn, whereas Gabriel knows it is coming and understands its potential terrifying force. In the mythological story, only a pious pair is left to repopulate the race. In Hardy's novel, Bathsheba and Gabriel are the ones who remain sober during the storm and save the farm. At the end of the novel Gabriel and Bathsheba are reunited in their natural world; but Fanny, Troy and Boldwood, being out of sympathy with nature and circumstance, succumb to their own unnatural existence. Hardy thus makes use of two versions of a furious storm, the biblical Noah's Ark account and the mythological storm born of Jupiter's wrath, to enrich his characterizations of protagonist and villain.

As earlier noted in connection with the choice of names for characters, merging of classical mythic and christian can be seen also in Hardy's use of the stories of Noah's Ark and of Jupiter's wrath during the Iron Age. Certainly the name Gabriel clearly evokes the Angel Gabriel of the Bible with all the pure and noble connotations so suggested. But "Oak" adds the myth of the pastoral, a derivative classic element, with its accompanying illusion that simple folk and 
the simple life are nobler than the sophisticated-but-evil city and its debased folk. Hardy's skill lies in not oversentimentalizing the pastoral ideal. True, simple country folk could be noble (Tess) but they could also be venal (Alec d'Urberville), stubborn (The Reddleman), cruel (Michael Henchard), ignorant (the Durbeyfields), arrogant (Eustacia Vye), indecisive (Jude), self-centered (Angel (lare). These mixtures of rather specific reference by nomenclature with more subtle reference to similarities of character or story-line are pleasant to recognize, enhancing the drama of the plot, sometimes even amusing; and they can be appreciated to whatever extent the reader's classical or Christian or pastoral background meets hardy's. These elements are introduced so naturally by Hardy that they escape intrusiveness which might impede the dramatic progress of the story.

Ronald Blythe points out, in the Penguin edition of Far Exom the Madding crowd, a prevalence of a interrelationship between classical and religious myth throughout the novel: Here we note Latin as Gabriel calls "ovi," the names of Gabriel and Joseph of religious source, Ephesians, Corinthians and Thessalonians from various old and New Testament works, winding up with a funny piece of dialect by Henery :

This village [Weatherbury] is as much the territory of Hardy's readings in classical mythology as his boyhood involvement in church services. "Ovey, ovey, ovey!" (from the Latin 
ovi, sheep) calls Gabriel to his flock. "Yes," says Joseph in a later crisis, "and I was sitting at home looking for Ephesians, and says I to myself, 'Tis nothing but Corinthians and Thessalonians in this danged Testament,' when who should come in but Henery there: 'Joseph,' he said, 'sheep have blasted their selves." These two sources of Hardy's literary version of Wessex cross and re-cross each other to the end of the novel, and with perfect euphony. Against them we encounter, for the first time in a major key in Far from the Madding Crowd, his own creed, his own commentary. (35)

HEBRAIC

Hardy's writings further reflect the Hebraic-Hellenic conflict so central to the Victorian mind. Matthew Arnold catches the conflict between the two worlds when he says in Culture and Anarchy, "The uppermost idea with Hellenism is to see things as they really are; the uppermost idea with Hebraism is conduct and obedience. . . The governing idea of Hellenism is spontaneity of consciousness; that of Hebraism, strictness of conscience. Christianity changed nothing in this essential bent of Hebraism to set doing above knowing" (109). As Matthew Arnold points out, "Selfconquest, self-devotion, the following not our own individual will, but the will of God, obedience, is the fundamental idea of this form, also, of the discipline, to which we have attached the general name of Hebraism" (109110). In Tess, Hellenism is more prevalent than Hebraism. 
As indicated in the first chapter from Rutland's writings on Hardy, from an early date the classics in general and Greek tragedy in particular played an important part in Hardy's intellectual and emotional life. "It is not until the mid-1870's, however, that it is possible to find any significant impact of his interest in Greek literature and thought on his own work" (Björk 46). Hence, in Far from the Madding Crowd the allusions to the classics abound. However, it is not until Tess that the Greek Hellenistic involving nature worship and scientific study will be seen.

\section{WESSEX/WEATHER}

Weather as a component of nature is used often to set mood or tone. However, like all these other categories, it does not exist isolated from other forms of imagery. In Far from the Madding crowd, the effect of mythic imagery in relationship to the weather is to create other little stories or "myths" in our mind which are superimposed upon the primary plot.

At times the stories use nature, particularly the weather imagery component, as in the striking parallels between the religious story of Noah's Ark and the mythic equivalent in the storm scene. Not only is the weather imagery more mythic in Far from the Madding crowd than in Tess of the d'Urbervilles, but also the structure of the novel has a mythic feeling with Hardy's use of the ancient 
kingdom of Wessex as well as the names of characters deriving from classical and Christian names. It should be noted that much of the novel circulates around Bathsheba's ancient house which is outside of a town called

"Weatherbury."

In the Author's Preface to the 1902 edition of Far from the Madding Crowd, Hardy points out that he is beginning to use the term Wessex for the first time giving the area of Dorset mythic proportions:

In reprinting the story for a new edition I am
reminded that it was in the chapters of 'Far from
the Madding Crowd, as they appeared by month in
a popular magazine, that I first ventured to adopt
the word 'Wessex' from the pages of early English
history, and give it a fictitious significance as
the existing name of the district once included in
that extinct kingdom. (47)

Also, Wessex as a concept but very much as a place and therefore an actual environment and climate in southern England may account for some of Hardy's weather imagery. Thomas Hardy's Personal Writings quote Hardy as saying "that continent [Europe] becomes virtually a province--a Wessex, an Attica, even a mere garden--and hence is made to conform to the principle of the novels, however far it outmeasures their region" $(44,48)$. Here Hardy is connecting Wessex with the classical association of Attica, part of ancient Greece surrounding Athens. As Jonathan Wike points out about Hardy: "Wessex which he discovers, appropriates, recreates and transforms has enlarged Hardy's 
reputation both as a realist and as a myth-maker" (55).

Hands, in his book Thomas Hardy: Distracted Preacher?,

says :

Allusion, which links a particular contemporary experience with some more generally known preceding one, is a literary technique well suited to the presentation of the continuity of communal tradition. Hardy's 'Poetical Matter' notebook shows him attempting to link the Wessex of his childhood with the customs of Classical times, but the use of biblical parallels and references is equally if not more pervasive in Hardy's presentation of the environment. (46)

Besides the reference to Wessex as myth, there is also specific symbolism associated with the elements of the climate. For example, although flood is one indication of passion, Boldwood's association with the frozen elements of the snow in chapter 16, which parallel the fixation on the Valentine received from Bathsheba, is another. As Lewis Horne points out:

The winter background described in this chapter carries no reference to the floods and tides that characterized the momentum of earlier passions. Everything points toward obsession, toward emotions stopped and fixed, and toward dislocation. . . Distortion, disturbance-these qualities are reflected in the same chapter in the strange way the light is cast off the snow, a "prenatural inversion of light and shade" (151) that mirrors the dramatic upset in Boldwood's emotions. But important as well is what snow-moisture frozen, stilled--suggests. If flooding water is reflective of passion and its effects, then snow is an apt register of the effects of Boldwood's passion, of the heavy imprint the Valentine and its two words "MARRY ME" set upon him. What is frozen does not change. (42-43) Hence, Gabriel is the only one who has the imagery of 
the Ark which associates him with survival, whereas, the mythic weather imagery, at times, surrounding Boldwood and Troy is of snow and freezing foreshadowing their deaths. The gurgle in the river, the laugh of men in the barracks and the "Gurgoyle" at Fanny's grave point out that Troy is a figure of derision rather than the heroic figure which Fanny seeks. Hardy uses the imagery of fixation or obsession of the frozen weather in association with Boldwood rather than the fluidity and change of water in the storm.20

Weather creates atmosphere, also known as mood, which fosters in the reader expectations as to the course of events, whether happy or terrifying or disastrous.

After Bathsheba rejects Oak, "It was a still moist night" (85). The comfortable atmosphere of good weather is changing to discomfort if not foreboding. Soon after, Oak's ewes are dead and his faithful but inexperienced sheepdog also.

Tragedy is introduced by a dramatic change of weather as Fanny Robin comes looking for Troy at his barracks hoping he will marry her, only to be put off again. The climax of

20 "Over the west hung the wasting moon, now dull and greenish-yellow, like tarnished brass. Boldwood was listlessly noting how the frost had hardened and glazed the surface of the snow, till it shone in the red eastern light with the polish of marble; how, in some portions of the slope, withered gross bents, encased in icicles, bristled through the smooth wan coverlet in the twisted and curved shapes of old Venetian glass" (Hardy, Far from the Madding Crowd 151). 
the weather, obliteration by snow, "had been reached tonight on the aforesaid moor, and for the first time in the season its irregularities were forms without features" (134-35). In the following lines weather imagery sets up an expectation of happy rejuvenative events. "It was now early spring" (172), as Mr. Boldwood suffers his unexpressed love for Bathsheba:

The winds, which had been blowing east for several weeks had veered to the southward, and the middle of spring had come abruptly--almost without a beginning. It was that period in the vernal quarter when we may suppose the Dryads to be waking for the season. The vegetable world begins to move and swell and the saps to rise. (172)

Here images of classic nymphs of the woods and forest

reinforce impressions of spring, invoking the desirable virgin, Bathsheba, to show mercy to the lovelorn.

The weather had gone distraught with springtime beauty. Hardy calls it "a teeming time" (194).

Here, by contrast, the weather creates feelings of terror and potential disaster. Portents of a huge rain storm after the marriage of Troy and Bathsheba are visible and represent some of the most dangerous weather for the characters :

One night at the end of August, when Bathsheba's experiences as a married woman were still new. . - The night had a sinister aspect. . . Thunder was imminent, and, taking some secondary appearances into consideration, it was likely to be followed by one of the lengthened rains which mark the close of dry weather for the season. (297) 
Superstitions predict weather change. Gabriel Oak kicks a frog. "The intimate association of frogs and toads with water earned for them a reputation among primitive peoples as custodians of rain" (Firor 131). When Gabriel Oak found a toad crossing his path, his fears of a storm were confirmed. Gabriel "knew what this direct message from the Great Mother meant. And soon came another" $(300)$.

$$
\begin{aligned}
& \text { Hardy uses the figure of mother, just as he uses } \\
& \text { the figure of God, as a convenient representation } \\
& \text { of the creative force, since both figures have a } \\
& \text { familiar connotation to all readers and obviate } \\
& \text { unwieldy circumlocutions. (stevenson 268) }
\end{aligned}
$$

Next Oak finds a garden slug which was "Nature's second way of hinting to him that he was to prepare for foul weather" $(300)$.

Peter Casagrande in Unity in Hardy's Novels:

'Repetitive Symmetries' points out that mother nature can be both benevolent and sinister even in the same phenomena of weather. Before the storm begins there is a benevolent "direct message" in the form of the slug and toad. As Casagrande states, "Nature in this mood seems benevolent enough, though in the form of the violent electrical storm she will display 'sinister,' 'lurid,' and destructive faces as well" $(110)$. Hence, weather imagery has the psychic releases of fairy tales of the good fairy god-mother and the evil step-sisters in the same story. In that way nature is like people who can be both good and bad in the same person. Hence, the storm has the mythic combination of the 
benevolent and the malicious God in the same weather phenomena.

Two black spiders also walked the ceiling and dropped to the floor. The sheep, whom Oak knew best, were in a protective circle with tails pointed toward the storm:
It was Gabriel Oak who sums up the countryman's extraordinary weather lore. Oak's was an elemental sympathy with nature; he spoke and understood her familiar language. The sky, the air, the behavior of every living creature he met, spoke of the approaching thunderstorm, and cold rain which was to follow. This memorable prelude fills the reader himself with an almost electric nervousness. The sheep knew all about the thunderstorm, but nothing of the cold rain; the creeping things were well aware of the discomfort of the rain, and were doing their best to hide away from it. (Firor 132)

The disharmony with nature of the three (Fanny, Troy and Boldwood) can be sensed in their association with cold snowy weather. Troy is first introduced when Fanny comes to see him in his barracks on a cold wintry night. Through the severity of a terrible snowstorm the reader senses that this relationship is somehow doomed. In the chapter entitled, "Outside the Barracks--Snow--A Meeting," the description of the snow scene gives the feeling of disharmony in the relationship between these two beginning with "irregularities" and ending with the visual lack of distinctiveness between heaven and earth:

This climax of the series had been reached tonight on the aforesaid moor, and for the first time in the season its irregularities were forms without features: suggestive of anything, proclaiming nothing, and without more character than that of being the limit of something else-- 
the lowest layer of a firmament of snow. From this chaotic skyful of crowding flakes the mead and moor momentarily received additional clothing, only to appear more naked thereby. The vast arch of cloud above was strangely low, and formed as it were the roof of a large dark cavern, gradually sinking in upon its floor; for the instinctive thought was that the snow lining the heavens and that encrusting the earth would soon unite into one mass without any intervening stratum of air at all. (134-135)

The claustrophobic end of this chapter indicates that Fanny is caught in a whirlpool from which only marriage can release her. The "gurgle" of the river here will be heard again from the "Gurgoyle" over her burial plot. The pathetic nature of Fanny in this scene gives the feeling that she will not be released from this downward spiral of the unwed-mother but that instead her life may end in tragedy (as in fact it does). Then we hear again the gurgle as a kind of mindless Greek chorus commenting on the scene: An expostulation followed, but it was indistinct; and it became lost amid a low peal of laughter, which was hardly distinguishable from the gurgle of the tiny whirlpools outside. (138)

Boldwood is also associated with snow as he becomes obsessed and frozen on the idea of marrying Bathsheba after he receives the Valentine in February. In this situation Bathsheba is like the goddess Venus, attired by the seasons, sending her son Cupid as a messenger in the form of the 
Valentine to Boldwood.21

This Valentine is sent light-heartedly but it is received very differently. There is a mention of unnaturalness in the scene as Boldwood will later become unnatural, letting the storm destroy his crops, and by the end of the novel doing the unnatural act of murder. "His window admitted only a reflection of its rays, and the pale sheen had that reverse direction which snow gives, coming upward and lighting up his ceiling in an unnatural way, casting shadows in strange places, and putting lights where shadows had used to be" (150).

There is here, as with Fanny and Troy, a reference to the idea of the confusion between heaven and earth of "that before-mentioned preternatural inversion of light and shade which attends the prospect when the garish brightness commonly in the sky is found on the earth, and the shades of earth in the sky" (151). The fixed element of Boldwood's thoughts are reflected in the snow: "the frost had hardened and glazed the surface of the snow, till it shone in the red light with the polish of marble" (151); "footprints of a few birds, which had hopped over the snow whilst it lay in the state of a soft fleece, were now frozen to a short permanency" (151). Hence, Fanny and Troy, and Boldwood are

\footnotetext{
21 Mythology explains that Cupid for a long time remained a childish little boy until venus got tired of her son's prankishness and had another child thus forcing Cupid to grow.
} 
associated with unnaturalness; whereas, Gabriel and Bathsheba, although she is fascinated temporarily with Troy, are associated with naturalness and the Golden Age in their relationship to nature and the weather.

Gabriel and Bathsheba, on the other hand, represent the natural world and traditional values. When they change, they change in harmony with nature and the rural life, whereas, the other three main characters try to force change in unnatural ways and are associated with Hardy's view of the dangers of urbanization. Bathsheba and Gabriel experience the happy ending of the pastoral; whereas, Boldwood ends in incarceration and Fanny and Troy end in death.

\section{ROMANTICISM/GOTHICISM}

It becomes necessary to recognize and explore a more contemporary influence known as Romanticism, and derivative gloomy Gothicism, while noting the strong influences of Hardy's cultural past with its vast mythology. Thomas Hardy is sometimes considered "a late nineteenth-century Romantic," but this needs exploration and the Romantic Movement itself needs definition to make the appellation understandable. For sheer pervasiveness the Romantic Movement--although scorned by some as overwrought in its imaginings (the Gothic novel), weakening to character and theme (the great Goethe produced a lachrymose work, The 
Sorrows of Werther), narcissistic in emotional quality (Swinburne's treatment of sexual love in poetry)--produced many lasting effects in literature, music, and other arts. We follow the road from Greece, home of the "pure" European classic, to Italy and France which added new flavors of their respective spirits and styles to the arts between 1820 s and the 1840s. While Rousseau is generally considered the father of Romanticism, the first outcropping of a "Romantic Movement" occurred in Germany with the early works of Schiller, and the philosophies of Kant, Fichte, Schelling and Hegel. Later in the eighteenth century came the English Gray, Collins, Cowper, Burns, Chatterton, Blake and the Gothic novel. From 1789 to 1832 English Romantics appeared: Wordsworth, Coleridge, Shelley, Byron, Keats, Southey, Campbell, Moore, Lamb, Hazlitt, and others.

The spread of the romantic ideal was greatly stimulated by the French Revolution, while German idealism pervaded the continent and was admired in England and America. No writer, especially with the historic background and modern sensibilities of a Thomas Hardy, could have been impervious to all this, and we know that he was not. Although Hardy did not benefit from wide travel (no Grand Tour of Europe for him), he was indeed lucky in a tutoring which caused his mind to travel the romantic road from ancient Greece to England and to take in his native land and its people as closely as any contemporary writer. It also 
gave him the wide sympathies of the sojourner in many English places rather than those of a traveler. It enabled him to understand the simple farmer as well as the privileged, women as well as men, the builder as well as the architect.

This kind of a consciousness was ripe soil for the romantic spirit, and it becomes necessary to ask, "What is this Romanticism?" and since we can not define it, its characteristics must be understood.

It is common to suggest that, in emphasizing the imagination over intellect, the Romantic Movement is classified as a reaction to neoclassicism which emphasized traditionally classic values such as sense of form, balance, discipline, dominance of reason, restraint, unity of design and aim, clarity, and proportion.

J.A. Cuddon also shies clear of defining Romanticism, calls it "a word at once indispensable and useless" (586590). He further prepares us for the disrepute into which Romanticism fell when it began to exhibit characteristics of maudin devotion to an ideal or intemperate emotional expression or mere sentimentality. He cautions that while the words "romantic" and "Romanticism" may be useless, they are needed to evoke all measure of varied response ranging from repugnance to enthusiastic approval. In the same way we are "stuck" with the closely allied terms: classic, classicism and neoclassicism. 
Harsh judgments have been made about Romanticism. Goethe equated classicism with health and Romanticism with weakness. But there are others who hold that Romanticism brought a kind of renaissance, a re-discovery, a wholly beneficial upheaval of a much-needed rejection of defunct standards and beliefs which resulted in a creative freedom of mind and spirit (Cuddon 122-124). No doubt the truth, as usual, lies somewhere in between, yet only attainable in the ideal of opposites.

Some have found great ways of making fun of English

Romanticism. Richard Armour offers:

English literature continued after the PreRaphaelites. For instance there is Thomas Hardy, an author who, according to one critic 'embraced most of the Victorian era and more than a quarter of the twentieth century.' In addition to this fact, Hardy wrote novels in which he somehow managed to make everything come out for the worst. Return of the Native has a typical Hardyan ending: Mrs. Yeobright is bitten by a poisonous adder, her son Clym stumbles over her body, and Eustacia Wildeve drowns. Egdon Heath, where man is always struggling against Fate, is the gloomiest place since the Brontes' moors. (143)

David Daiches is more admiring of Hardy's inspiration.

"While Nature can be healing to receptive persons, it is indifferent to Man and cannot protect him from disaster. This hard fact provides Hardy's essentially tragic view of life" (158). Finally, A.S. Byatt, English novelist-critic, puts Hardy into the extremely rare company of those writers who were to search the innerself to establish or deny harmonies with exterior influences when he includes him 
along with Lawrence, Woolf and Joyce as one who projects a "strong literary personality to which, in the phrase of today's innocent student, one can 'relate'" (94).

Lacking a definition, Benet assays to define "romantic" characteristics:

Broadly, Romanticism might be said to involve the following characteristics: individualism; natureworship; primitivism; an interest in medieval, Oriental, and vanished or alien cultures in general; philosophic idealism; a paradoxical tendency toward both free thought and religious mysticism; revolt against political authority and social convention; exaltation of physical passion; the cultivation of emotion and sensation for their own sakes; and a persistent attraction to the supernatural, the morbid, the melancholy, and the cruel. (871)

Illustration of the same or similar quality from Hardy's works will be given for some of these. Two characteristics point to the connection between Romanticism and Gothicism: an interest in medieval, Oriental, and vanished or alien cultures in general; and a persistent attraction to the supernatural, the morbid, the melancholy, and the cruel. Anna Wittmanm in her chapter, "Gothic Trivialliteratur: From Popular Gothicism to Romanticism," in European Romanticism connects these two characteristics with Gothicism when she speaks of the folkloric background of literary Gothicism:

"Suspense and the supernatural, often fused with exotic and medieval settings, characterize the eighteenth- and nineteenth-century equivalents of the modern thriller" $(60)$. In fact, Hardy has taken the title of his book, Fax 
from the Madding Crowd, from lines in Thomas Gray's

graveyard poem, "Elegy Written in a Country Churchyard." In this poem, Wittmann says there are "many manifestations of the preoccupation with the sepulchral trappings of death and ruins that are to pervade Gothic literature" (61-62). The section of Far from the Madding Crowd, with the focus on Fanny's coffin in Bathsheba's house and Troy's concern with putting flowers on her grave, connects the Gothic mood of melancholy from Gray's poem through the title into Hardy's novel.

Also in Far from the Madding Crowd can be seen an interest in medieval, Oriental, and vanished or alien cultures in general as in the gargoyle on the medieval church through which water spouts on Fanny's grave. The classical and biblical names send the reader back to extinct cultures. This shows the connection of Romanticism to Hellenism as writers tried to recreate the ancient life of the classical Greeks.

Another element of Romanticism can be found in the Gothic description of the electric storm. What followed was a terrific electrical storm with portents of evil and disaster:

Then came a third flash. Manoeuvres of a most extraordinary kind were going on in the vast firmamental hollows overhead. The lightning now was the color of silver, and gleamed in the heavens like a mailed army. (306) 
A chapter entitled, "The Storm" in Harrison Ainsworth's

Rookwood begins with similar imagery. "The night was wild

and stormy. The day had been sultry, with a lurid,

metallic-looking sky, hanging like a vast galvanic plate

over the face of nature" (109). In addition, F.B. Pinion

points out that Far from the Madding crowd shows the

influence of the Gothic in the description of the storm in

supernatural terms.22

Hardy ventures into cosmic landscape in the wildly

sublime storm in Far from the Madding crowd. First the

lightning outlines earthly matters; then the outline

explodes into a picture:

On the slope in front of [Gabriel] appeared two human shapes, black as jet. . . . It had been the sixth flash which had come from the east behind him, and the two dark forms on the slope had been the shadows of himself and Bathsheba. . . . [Then] there was more light, and he saw as it were a copy of the tall poplar tree on the hill drawn in black on the wall of the barn. Heaven opened then, indeed. The flash...

22 "Professor Weber found a startling resemblance between the storm in Harrison Ainsworth's Rookwood and that in Far from the Madding Crowd (XXXVI-XXXVII). The 'sinister aspect' of the night, the 'lurid metallic look' of the moon, the breeze which seems as if breathed from the parted lips of some dragon about to swallow the globe,' the 'forms of skeletons' which appeared in the air, and with which were intertwined 'undulating snakes of green' in the lightening's 'perfect dance of death.' the sulphurous smell which ensued, and the silence 'black as a cave in Himmom' when lightening and thunder ceased, are not all evoked by phrase or suggestion in Ainsworth, but they indicate how vividly Hardy's youthful imagination was impressed by such scenes as that in Rookwood. It is interesting to note that the hero of that novel is impersonated by Troy at Greenhill Fair" ( Hardy Companion 154). 
sprang from east, west, north, south, and was a perfect dance of death. The forms of skeletons appeared in the air shaped with blue fire for bones--dancing, leaping, striding, racing round, and mingling altogether in unparalleled confusion. (308)

Gabriel plays the role of the sober hero during the

storm:

Not a drop of rain had fallen as yet. He wiped his weary brow, and looked again at the black forms of the unprotected stacks. Was his life so valuable to him after all? What were his prospects that he should be so chary of running risk, when important and urgent labour could not be carried on without such risk? He resolved to stick to the stack. (306-307)

Enstice points out that "these roles come to life vividly in the most powerfully described event in the whole novel--the thunderstorm after harvest supper" (59).23 Again an example of the presence of the supernatural in the weather imagery of nature in Far from the Madding Crowd exists in the description of fog at Fanny's funeral: "and by the time that horse, man, and corpse entered Yalbury Great

23 "Oak's weather-reading skills, like his ability in deciphering the stars, are evidence of the harmonious existence of such a community in nature. The landscape of fields and farm comes alive in detail, and acts in close harmony with the man whose life is a part of the same landscape. Even at the height of the storm, Oak merges perfectly into the scene illuminated by each flash of lightening.

When the rain at last comes on in earnest he becomes as one with the sky and the earth. 'The rain stretched obliquely through the dull atmosphere in liquid spines, unbroken in continuity between their beginnings in the clouds and their points in him.' It is not a struggle to oppose the elements, but to harmonize with them, taking their strength and using it, and turning aside their destruction when it comes" (Enstice 59). 
Wood, these silent workings of an invisible hand had reached them, and they were completely enveloped, this being the first arrival of the autumn fogs, and the first fog of the series" $(341)$.

A further look at the gargoyle in Far from the Madding Crowd diverting torrential rain beyond the building onto the grave of Fanny reveals an abundance of reference as it forebodes chaotic events. Its atmospherics and gloomy tone, however, are so insistent in suggesting doom and destruction that the reader is perhaps more aware of their effect than impressed by the facts of the scene. Not only is water diverted but, when finally contrite, sorrowing Troy sincerely intending to honor Fanny at last, plants flowers on her grave, his intention is thwarted as the plants are swept away by the downpour from the gargoyle.

The gargoyle itself is a mixture of classical mythic, controversial pagan and Christian imagery. Creations of stone masons as practical attractive covers for downspouts to send rain beyond the footings of building, these sculptures are fantastic exercises in grotesquerie. Entwined with scrolls and leaves, they resemble human/animal figures and often appear to be spitting water on whomever is below. They can be variously interpreted as evil or prankish, threatening or protective. The gargoyle was used as far back as Greek and Roman times. Francis Bond in his book Gothic Architecture in Enqland says, "The gutter, 
gargoyle, and 'larmier' or coping were all in use in Greek and Roman work; but were re-invented by the Gothic architects of the thirteenth century" (399). Also the Oxford English Dictionary supports this by linkage of the gargoyle with classical Troy in its first reference to the town name of "Troy." "1412-20. Lydg. Chron. Troy. II, XI, And every hous keuered was with lede And many gargoyl, and many hidous hede" (57). Although the city of Troy is a real place, stories of Troy originate in the domain of mythology. Besides the allusions of the gargoyle, Hardy gives the character chiefly involved with the gargoyle the name "Troy," a name with mythic association.

Thus, the weather imagery is one of rain pouring through the mouth of the gargoyle and flaunting Troy's purpose, an image abounding with mythic associations. Perhaps the "Immanent Will" operates here as certainly as anywhere else in Hardy's novel to determine Fanny's fate and reputation even beyond the grave.

Hence, in Far from the Madding Crowd Hardy is naturally using his accumulated knowledge of myth and religious reference to advance his plot, character development and setting with the support of weather imagery. By the time Tess was produced, Hardy's images requiring the reader to visualize ancient persons, places, or events will be useful principally if they bear strongly on characters or advance 
the plot significantly. In the final chapters of the great novel, weather images will be reduced almost to a weatherman's catalog of meteorological observations. simultaneously, however, while lessening his use of decorative or enhancing image, Hardy will refine his use of imagery to produce in Tess of the d'Urbervilles a unity of heroine and the class of society she represents in a headlong progression to death through events preordained by her character, background and her life's experiences caught up in the overmastering metaphor of The Chase. 
CHAPTER III

Tess of the d'Urbervilies:

Science, Myth and the

Realistic Development of the Novel

\begin{abstract}
With the writing of Tess of the d'Urbervilles, Hardy has moved away from a mythological presentation of nature to one more realistic and factual. Looking at weather imagery, in particular, it can be seen that the weather no longer influences events and plots. By contrast with the earliex novel, Far from the Madding Crowd, weather in Tess reflects the near elimination of myth as happenings are described as natural phenomena and in more scientific language. Hardy has consciously moved his language to a more scientific plane to show that morals and ethics can distill nature out of life rather than being superimposed from an arbitrary set of values such as mythology or religion.

This more factual scientific description of nature is recognizable in examples of weather imagery from Tess, which seem to lack a mythological component. The wind in the following example is personified as a sighing soul but without any accompanying mythological scene. Wessex has fantastic atmosphere as the "occasional heave of the wind
\end{abstract}


became the sigh of some immense sad soul, conterminous with the universe in space, and with history in time" (70). Other examples of weather imagery as natural phenomena in Tess are: "It was a fine september evening (106); "a faint luminous fog, which had hung in the hollows all the evening, became general and enveloped them" (114); "Here under her few square yards of thatch, she watched winds, and snows, and rains, gorgeous sunsets and successive moons at their fuIl" (134); "On a thyme-scented, bird-hatching morning in May . . she left her home for a second time" (155); "the new air was clear, bracing, ethereal" (157); "Her hopes mingled with the sunshine in an ideal phosphere which surrounded her as she bounded along against the soft south wind" (157). Some atmospherics like an "ideal phosphere" remain but they are enhancers of natural settings, not mythological scenes.

Indeed, in Tess the weather appears most frequently to enhance the appearance of the cast of characters: "The hot weather of July had crept upon them unawares, and the atmosphere of the flat vale hung heavy as an opiate over the dairy folk, the cows and the trees. Hot steaming rains fell" (199). "July passed over their heads, and in its wake seemed an effort on the part of Nature to match the state of hearts at Talbothays Dairy" (207). The language in these two passages is emotionally heated but generally fairly factual and without gods or goddesses. 
What remains Greek in Tess, however, is more the ideas the Greeks held than the exact myths one sees in Far from the Madding Crowd. Hardy addressed the problem when Tess asks Angel not to call her by Greek names, which Tess does not like:

She was no longer the milkmaid, but a visionary essence of woman--a whole sex condensed into one typical form. He called her Artemis, Demeter, and other fanciful names half teasingly, which she did not like because she did not understand them. 'Call me Tess,' she would say askance; and he did. (187)

Tess, unlike Bathsheba in Far from the Madding Crowd, does not represent the biblical figure; the classical reference comes from the mind of the writer Hardy to assert the undeniable female attractiveness of Tess. In Far from the Madding Crowd the story of Noah's Ark, the storm, and Gabriel's subsequent survival invest Gabriel with enormous power and dignity, becoming a part of story and character rather than external labels as with "Artemis" and "Demeter" in Tess. In fact, Tess challenges Angel's use of the labels because she does not know what they mean. This "child of nature" does not even carry these mythic stories in her mind. When Hardy speaks of the "Cyprian image," again this comes from the mind of Hardy and runs the length of the novel not as a classical story line but as an intrinsic part of Tess's character:

He who had wrought her undoing was now on the side of the spirit, while she remained unregenerate. And, as in the legend, it had resulted that the Cyprian image had suddenly appeared upon 
his altar, whereby the fire of the priest has been wellnigh extinguished. (384)

As Charlotte Thompson points out in her essay, "Language and the Shape of Reality in Tess of the d'Urbervilles":

Much of the language represents an extension of Tess's thoughts. All the same, the "Cyprian image" cannot possibly spring from the mind of a girl who elsewhere does not even know the name "Artemis." Instead, the narrative voice shines through, caught up in the language of mythology, the same affinity that prompts the "Aeschylean Phrase" on the President of the Immortals. "Mythology," wrote Hardy, "according to the comparative mythologies, is, forsooth, only a disease in language--literal understanding of primitive metaphors." (743)

Hence, if Hardy saw mythology as a "disease of the language" then he would want to move away from reliance on its literal stories in his later novels.

In Far from the Madding Crowd, Hardy is using mythological imagery literally; in Tess he is dealing with the idea of the superiority of Hellenism to Christianity.

Rosemary L. Eakins, in her article, "Tess: The Pagan and Christian Traditions," discusses the idea of Hardy's preference of Graeco-Roman origins to Christianity:

Tess has been associated with a series of great female figures: Ceres, Cybele the many-breasted who in mythology was served by a priest who took a vow of chastity and then broke it, Artemis, Demeter, Eve, and the Magdalen. All of these are life-enhancing figures. Those of Graeco-Roman origin serve and impose natural laws which Hardy seems to feel are superior to the narrow lipservice Christianity of the Clare brothers, for example. The Christian figures, Eve and the Magdalen, forgiven and loved by Christ. (124) 
Hardy's early interest in the classics in general and Greek tragedy in particular plays an important part in Hardy's intellectual and emotional life. As Lenart Björk says in his article, "Thomas Hardy's 'Hellenism": "allusions to the Hellenistic life and aesthetics are prominent in Hardy's fiction, and particularly in Tess and Jude in which 'Hellenism' to an important extent provides the ideological and moral framework" (46).

Although Hardy in his Literary Notes mentioned Greek cruelty, barbarism (entries 502, 510, 565, 566), and falsehood (entries 507, 533, 535), the overwhelming evidence indicates a favorable impression of Hellenism:

Thus, Greek morality in general emerges as decidedly superior to modern, and Mahaffy's generalization that "no modern theology" has developed higher and purer moral notions than those of Aeschylus and his school (entry 552) is supported by various specific examples. Among others, Hardy records a reflection of Greek sexual morality in a note on society's view of women forced into sexual relationships: "When a town was captured, the noblest and fairest ladies become the concubines of the victors; such a fate was in no sense a dishonour of which they would afterwards be ashamed--merely a misfortune" (entry 509).

In Tess Hardy has moved to a latter-day Romanticism where Tess embodies for the romantic Angel those qualities of Romanticism associated with nature such as innate goodness of man in his natural state, reverence for nature, and primitivism. However, we see on the couples' wedding night that Angel fails in bringing together in his mind 
his romanticized Tess with the real Tess. Angel, hence, is a parody of the true Hellene because he can not find a balance between the romantic and the reality that would let him accept the truth and still see Tess as a pure woman of nature.

Hardy has residues of the romantics in Tess, complete with their attributes to Hellenism. Yet this novel shows that Hardy was working toward greater realism in his later narrative fiction as the influences of scientific development had permeated not only his conscious thinking with social issues such as the double standard, marriage, and questioning of religion; but also his unconscious was more scientific. Nineteenth-century scientific advances had unfettered his writing so that he was not bound to the exact details of his classical and biblical training; instead, he was creating his own purer more original story line.

This moves us to the various angles from which to see Tess. If Hardy had attached Tess to one mythic figure then she would not lend herself to various interpretations as readily. The mythological and religious images in Far From the Madding Crowd create visual images in our minds of these stories which dominate the novel. However, in Tess, permeation of nineteenth-century scientific thinking into 
the writer's unconscious has caused Hardy to use mythological image less for the specific stories of the classics and the Bible and more for conscious Iinguistic metaphors.

The deconstructionist critic, Jean Jacques Lecercle, points out in an article entitled, "violence of style in Tess," that specific Greek myths seen in Far From the Madding Crowd have given way to a linguistic violence of language in the metaphors of the hunt, chase and blood imagery in Tess:

If the novel is based on a contradiction (if it is a myth telling the age-old opposition between Nature and Culture, folklore and history, aeon and chronos), and if this narrative contradiction is a metaphor for the instability and violence of language, Hardy's stylistic contradiction is the best possible reflection of this. Hardy's stylistic gift is that he dares unleash the violence of language, that he does not attempt a mythical solution to the contradiction, but lets it stand and be perceived. (154)

Tess's last name illustrates a tension of corruption of nature by culture and history. The name of her family is Durbeyfield and a local family had "stolen" her upper class name, d'Urberville. Both the names contain the syllable "urb" which still more important contains the letters "UR" which means original, primitive or earliest and is associated in literature with the original as in the example of the UR-Hamlet. As Lecercle points out about Tess, this "country girl is the true descendant of the archaic nobility, much more so than the nouveau riche impostor who has appropriated her name, or the petty-bourgeois who dominate 
her world" (151). Lecercle also points out that the language of folklore is closer to the language of Chaucer and Shakespeare than to modern speech (152).

Another analysis of metaphors in Tess is found in Laura Claridge's article entitled, "Tess: A Less than Pure Woman Ambivalently Presented." This article proposes that Tess is somewhat of a biblical snake. The killing of Alec defies the message of the sermon on the Mount's idea of "turn the other check": instead, Tess takes on the old Testament idea of "an eye for an eye," with Alec's murder (substituting the phallus of rape with the phallus of the knife), although she maintains that she and her husband, Angel, still believe in the Sermon on the Mount.

John Holloway in "Hardy's Major Fiction," in From Jane Austen to Joseph Conrad, feels that there is another metaphor bigger than that of the chase and the blood which have always appeared to be central to the novel. This second metaphor is one that is certainly supported by Hardy's being imbued with scientific thought around the time of writing Tess. Holloway describes this metaphor, which he feels is more important than the Chase, as the Darwinian metaphor of "organism," "environment," "struggle, "adaption," "fertility," "survival," "resistance," and finally "extinction." It begins with Tess's organism, and the environment of the "Vale of the Little Dairies." Tess struggles to surmount the challenge of barren Egdon Heath which Iies across 
her path. Tess's adaption takes place when she enters the new territory of the "Vale of the Great Dairies," where life runs a different pattern and she adapts herself so much she finds a mate in Angel Clare. A new life almost succeeds in germinating here. Stress is laid on fertility during this period. Survival comes when the Rally, a phase out of history and natural history, fails. Tess abandons her favorite environment and is forced onto a harsh upland soil. She struggles not at a level of reproduction, but for mere survival. Her return to Alec is resistance to extinction; however, extinction does come at Stonehenge with Tess's subsequent death. Hence, according to Holloway, the Darwinian cycle is complete with Tess's extinction and another species better adapted to the environment, in this case her younger sister, Liza-Lu, a virginal Tess, must take over.

Also the idea of primitivism, which dominates the end of the novel, while a literary characteristic of the literary writer, can also be linked to Darwinism. Although Tess is not as Darwinian as Hardy's next novel, Jude the Obscure, Tess still contains Darwinian attitudes. One of those ideas, for example, is that of "appetite for joy which pervades all creation, that tremendous force which sways humanity to its purpose" (255). In Elliot B. Gosse, Jr.'s article, "Psychic Evolution: Darwinism and Initiation in Tess of the d'Urbervilles," he points out that Darwin's concept is connected with the initiation rite of blood. 
Alec's evolutionary regression to primitive times in the rape of Tess in The Chase shows this.

Gosse states: "In 1887, three years before beginning The Golden Bough, James Frazer had published Totemism, 24 an authoritative statement on a subject which Western man was just beginning to grasp. By 1889 Hardy would have known some of the rituals documented by Frazer, including a common form of totemic initiation, being 'smeared with blood"" (221). This ceremony is used with half-bloods who have lost much of their pure blood through intermarriage. The ceremony at their installation is "the touching of their foreheads with a drop of blood drawn from the body of a pure aborigine of the tribe, they belong to" (Golden Bough, 4243). The Golden Bough contains the inclusion of primitive blood rituals which Hardy noted in his Literary Notes II. 25

This custom of symbolic initiation among primitive tribes is imaginatively adapted by Hardy to form an important figurative pattern in the plot of Tess. It makes its appearance in the death of Prince, the seduction of Tess by

${ }^{24}$ Although we do not know if Hardy read Frazer's Totemism, in Hardy's Literary Notes he does comment on Frazer's The Golden Bough and its inclusion of primitive blood rituals.

25 "This The Golden Bough is a work of primitive superstitions and religion. The book treats of Priestly kings, sympathetic magic, rain making, inspiration by blood drinking at Argos, blood of a lamb--India \& c--live human gods (in South Sea islands)" (Literary Notes II 45). 
Alec in The Chase, the slaughter of rodents at harvest $(\mathrm{Ch}$. XIV), dreadful crime of the sixteenth or seventeenth century by an ancestor in the d'Urbervilles coach, postilion of the aristocratic carriage-poles (Ch. XXXIII), wounded pheasants with which Tess spends the night, and finally Tess turning on Alec and killing him. Besides being a victim of society. Tess reflects the evolutionary idea of progress and regression. Gosse points out, "After leaving Angel, Tess undergoes a reversal of psychic evolution. Having lost her chance of breaking free of Alec's seal, of becoming a fuller individual guided by Angel's high spiritual nature, she reverts first to the peasant level with her family, and then below that to the animal level after she leaves them" (226). "There was something of the habitude of the wild animal in the unreflecting instinct with which she rambled from her eventful post at every step, obliterating her identity."

The color red which is associated with blood is exploited in Tess with different permeations as well. J. Hillis Miller says in his chapter, "Fiction and Repetition":

The coarse pattern inscribed on Tess's flesh is, the reader assumes, traced out in red, and it should be clear now what meaning the reader should ascribe to all the chain of red things in the novel: the red ribbon in Tess's hair; her mouth - . : : those red lips with which she says the characteristic "UR" sound of her dialect; the strawberry that Alec forces her to eat...; the roses that Alec gives her with which she pricks her chin; the red scratches on her wrist in the reopening scene. . . ; the red stains made on Tess's arms when, in an extra-ordinary scene, she approaches closer under Angel's window, fascinated by harp playing, making her way through "tall 
blooming weeds emitting offensive smells." (5556)

Hence, the metaphor of the Chase and blood runs the length of the novel, tying man to his primitive nature and to the cycle of nature, the natural world of animals, and the elements. The cyclical nature of evolution connects itself to weather imagery in the cycles of the elements in the seasons. This connection of natural cycles of nature is seen in Garson's Hardy's Fables of Integrity:

The cycle of nature is presented as analogous to her own experience: as her fatal love for Angel develops, the sequence of Tess's emotion is echoed and exacerbated, by the waxing summer heat, so that the unfolding season itself seems to announce her fall. (29)

Yet another important metaphor is one involving society and the destruction of a whole class of workers. There are hints early on that farming is undergoing very rapid changes, that the "olde pesantry" is losing its relationship with the land. The poverty of Tess's family is land-related with the father being a poor farmer whose children are going to have to support him. It is Tess who harvests fields or works in the dairy. But these jobs become scarce as mechanical reapers take over. In the few years that intervene between Tess's life at the d'Urberville manor and her return in disgrace to her family home, the laborers' situation has markedly worsened. Machinery has turned their work into very hard, fast-paced toil. The rhythms of handlabor which allowed them moments to appreciate the weather 
and the scene around them are gone and with them the sometime happiness they had in the fields. Soon they will have no place on the land. They, too, are being hunted by progress, and the hunter is gaining on the fox. The metaphor of the fox dead in the bushes is surely signalling this societal death, or it seems irrelevant. When, however, the strong principal metaphor of the hunt begins to rush to its conclusion at stonehenge, no other plot metaphors intervene. The metaphor of the hunt of Tess has become the meaning and vital force of the entire piece.

The metaphors running through this novel gain importance as mythic weather imagery in this novel is de-emphasized for a more factual weather background. The specifics of Hardy's weather imagery, based on Hardy's influence from scientific thinking, become more simply weather reportage, as was inevitable in his thinking. Weather imagery does play a part, however. Specifically, weather imagery is used to increase the actual hardship of farm labor. Although Hardy links the barren and crippling toil of life on the upland farm of Flintcomb-Ash to an absentee landlord, the essential things that make farm work hard are those which have made rural life hard since the beginning. These have to do with the environment and the weather: stony soil, cold wind, rain, and snow. Hardy describes the barrenness of Flintcomb-Ash. "There was no exaggeration in Marian's definition of Flintcomb-Ash farm as a starve-acre place" 
(360). The weather the laborers must endure adds to the

harshness of the existence as seen in these lines from Tess:

In the afternoon the rain came on again, and Marian said that they need not work anymore. But if they did not work they would not be paid; so they worked on. It was so high a situation, this field, that the rain had no occasion to fall, but raced along horizontally upon the yelling wind, sticking into them like glass splinters till they were wet through. Tess had not known till now what was really meant by that. There are degrees of dampness, and a very little is called being wet through in common talk. But to stand working slowly in a field, and feel the creep of rain-water, first in legs and shoulders, then on hips and head, then at back, front, and sides, and yet to work on till the leaden light diminishes and marks that sun is down, demands a distinct modicum of stoicism, even of valour. (361)

The rain and wind gives way to the harsher elements of frost and snow. Here Hardy presents the icy weather as a horrifying experience to live through as seen in the tragical eyes of the birds from the North Pole. He calls them:

gaunt spectral creatures with tragical eyes-eyes which had witnessed scenes of cataclysmal horror in inaccessible polar regions of a magnitude such as no human being had ever conceived, in curdling temperatures that no man could endure; which had beheld the crash of icebergs and the slide of snow-hills by the shooting light of the Aurora: been half blinded by the whirl of colossal storms and terraqueous distortions; and retained the expression of feature that such scenes engendered. (363)

This scene juxtaposes an ice-age existence of the birds to the harsh realities of the Dorset laborer as he toils through the winter. Here a ghastly scientific reality based on paleontology is juxtaposed to the mood set by the 
weather. This description underscores Hardy's insistence in the novel upon the essential harshness of rural life.

Weather reflects the continuing "looped cycles" of evolution in Tess. The harsh weather of Flintcomb-Ash is at another point in this cycle from Talbothays's weather which goes with its fertility. The book is divided into phases which in itself indicates cycle changes as in the phases of the moon. The moon, as well as the sun, also has a cycle through which it passes in its orbit. After passing through many phases of running, hiding, running, the cycle for Tess ends at stonehenge, itself a symbol of peace and eternity. The position of the stones at stonehenge underscores this circular element as the stones themselves had been placed by ancient man in a rough cyclical formation. This moves us to the concept of angles of perception which intersect the subject from different positions as if on a sphere. Tess is seen differently by various characters in the novel. Hardy maintains and communicates to the reader the clearest vision keeping Tess always "beautiful Tess." In terms of weather imagery, Alec and Angel are often seeing Tess through the mist or fog of their own ideology and perception of a woman.

Janet Freeman refers to this in her article, "Ways of Looking at Tess":

Obscured by mist--as when Tess and Angel walk around Talbothays at dawn (XX, iii; XXXI, 164), by fog--as when Tess and Alec wander in the chase on the fatal night (XI, 59), by snow--as when 
Tess and Marian labor on the fields of FlintcombAsh (XIIII, 241), even the Iandscape is unstable, a "psychological phenomenon" (XII, 72) that habitually expresses the changing experience of its inhabitants, the changing lights of day and night, and the changing seasons of the changing year. over and over the merciless sun is noticed as it rises and sets, casting "fantastic mysteries of light and shade" (L, 288) on the turning world beneath it, and bringing Tess's future inexorably to pass. (317)

As George Wotton in "Towards a Materialist Criticism," in Tess of the d'Urbervilies: Thomas Hardy, points out at Talbothays sundays are really sun's day, "when flesh went forth to coquet with flesh while hypocritically affecting business with spiritual things" (37). There is the "oozing fatness and warm ferments of the Froom Vale." The associations here are with "the communal, the customary, with physical labor, natural instinct, sexuality with the essential paganism which lay concealed beneath this apparently Christian community" (37).

Also the sun at stonehenge is connected to the hypocrisy in both paganism and Christianity. When Tess awakes to meet her fate, it is a sun-day in another sense than the Christian-honored, modern rest day of the week. It is perhaps the dawn of a absolutely clear day, a day of reckoning with fate, cause and effect on a straight course to intersect the peace circle of retribution. "The dawn shone full on the front of the man westward. . . It was the head of a man approaching them from the hollow beyond the sunstone" (486). He seems to be walking in a straight line. 
Even the breezes at stonehenge are directional. Again at Tess's hanging the weather is clear. There are no more clouds or mists to obscure things. There is a breeze at her hanging which is blowing the black flag straight out. Breezes also clear away clouds and fog. "The President of the Immortals had ended his sport with Tess" (489); hence society was on a straight legal course, no longer playing with Tess.

Angel talks about his family's beliefs in terms that sound scientific: geocentric, zenithal and nadiral. However, he is describing a way of thinking that is old fashioned and pre-Galilean, before people realized that man was not the center of the universe. Angel shows that he has eschewed the psychic life at his father's vicarage in the following terms :

Its transcendental aspirations--still unconsciously based on the geocentric view of things, as zenithal paradise, a nadiral hell--were as foreign to his own as if they had been the dreams of people on another planet. (218)

In "Psychic Evolution: Darwinism and Initiation in Tess of the d'Urbervilles," Gosse says: "But once we have seen what Hardy intends us to focus on, we can sympathize with Tess's struggle to advance on the scale of psychic evolution and we can appreciate the insight Hardy showed in connecting the psychical and the physical, in rendering the struggles of mind through evolutionary and ritualistic images" (223). 
Gosse says,

Although Hardy favored evolution with its sympathy and cooperation, he did not forget natural selection with its competitive lack of compassion. . - It is evident, therefore, that despite Hardy's hatred of cruelty and his hope that in man cooperation based on evolutionary kinship would overcome competition based on natural selection, he recognized the strong hold of the more brutal means of maintaining relations. . . . In Tess Darwinian self-assertion manifests itself in an aggressive-submissive pattern which has its locus in the relations of Alec and Tess but is generalized to include society. past and contemporary. (224)

In addition, Gosse states:

She stabs Alec to sever finally the blood bond between them. The image describing his fate is very similar to that used in the scene with Prince, whose death was almost directly responsible for putting her under Alec's domination. The wound was small, but the point of the blade had touched the heart of the victim. Murdering him is the only way left to her, and to do it she has to regress as far down the human scale as Alec had in The Chase, back that is to the pagan Druids. (227)

When Angel refers to Tess as Artemis and Demeter he is making reference to moon goddesses. Max Müller, who is identified with sun-worship, says in his book comparative Mythology:

The whole of nature was divided into two realms-the one dark, cold, wintry, and deathlike, the other bright, warm, vernal, and full of life. The treasure of the earth... the nebulous powers of winter and darkness had carried away like robbers. The vernal sun wins it back, and like Demeter, rich in the possession of her restored daughter, the earth becomes rich again with all the treasures of spring. (138-139) 
Artemis is associated with sun-worship as Apollo is the sun; Artemis, his sister, is the moon. Also Artemis was the Lady of Wild Things, protectress of the Hunt. This metaphor runs throughout the novel as well as the sun-worship which plays an important part in a final scene in Tess. The conclusion of Tess uses ancient stones if not created by man at least placed and erected by him. Huge rocks, they might be calculated to threaten or destroy the characters of the novel; instead, they become a resting place where Tess lies calmIy and awaits her fate. Similarly the weather is characterized by a gentle wind which is merely directional, pointing the way to the Great Monuments. Angel calls stonehenge "a very Temple of the Winds" (484).

Hardy has chosen a scientific association for this final scene with stonehenge, evoking Druidical ceremony and astronomical observation where things come into balance for Tess because she has thought her way through her own problems and those of Angel and her sister as well. In a setting rich with possible Druidic science and a non-threatening breeze directing her to this place, indeed "a very Temple of the Winds," Tess achieves clarity, purity and balance on her own because Angel's unresolved sense of Christian guilt will not permit him to fully understand or forgive her:

Angel's great sin thus becomes archetypal. In refusing to accept Tess's "experience," in continuing to see her imagined newness irretrievably stained by the seduction, 
he denies the capacity of Nature to be infinitely old and experienced and yet forever new

and virginal. (Johnson 277)

Tess awaits the officers who will take her to her execution as a murderess.

If this ending had been written twenty years earlier with so much unresolved from the ancient past and about Tess's own connections with the dubious character and doubtful honor of her d'Urbervilles ancestors, the novelist might have used this earlier vehicle of portentous weather images to suggest doom and gloom. Instead, the officers appear around Tess in glistening early morning light, approaching quietly almost respectfully and with the dawn shining "full on the front of the man westward" (486) as the ancient scientific Druids had planned. If Hardy had wished to make further dark implications about Tess, his ever-present tools of nature and especially weather were available. "Invisible hand," and "restless Pleiades" and "obliterative snows" would seem out of place in this late nineteenth-century rational atmosphere. The serenity of this conclusion in which "the light was strong, and a ray shone upon her unconscious form, peering under her eyelids and waking her" (487) releases Tess from the tempests of the past.

Eighteenth-century Enlightenment, nineteenth-century Christianity limited by Victorian social values and late nineteenth-century Darwinian theory have joined in Hardy's thinking for a resolution which enables Tess to retain her 
perception of herself as "pure" and at the same time to accept society's official solution to her social transgressions.

Science, then, has brought to Tess a considerable measure of clarity and order and peace in a formerly chaotic human dilemma and has accomplished it through the consciousness and mind of Thomas Hardy's mature heroine, once the untutored child-of-nature, Tess. The storms of her life have calmed to gentle breezes. Finally, Wickens in "Hardy and the Aesthetic Mythographers: The Myth of Demeter and Persephone in Tess of the d'Urbervilles" underlines Hardy's progression from myth to science in Hardy's development of the novel:

The development of Tess's thoughts and feelings retrace the evolutionary 'progress' of Western man from the age of myth to the age 'whose conception of the universe has been formed by science, whose thought is critical and reflective.' (104) 


\section{CONCLUSION}

Hardy's work is seen as a product of the classical thinking of his time plus the ever growing scientific transformations of nineteenth-century depictions of nature. Far from the Madding Crowd still shows marked pastoral, classical and mythical influences, and strong biblical references in the characters. Tess of the d'urbervilles, the later novel, portrays characters in a realistically believable environment where nature exists as physical fact but does not influence human behavior in a mythic way.

A reading of the two novels offers a movement from the romantic notion of the ideal in nature and its accompanying view of purity in Far from the Madding Crowd to an emphasis on individual examples in Tess. In Tess Hardy has modernized the contemporary view of the heroine tainted by illegitimacy, the stereotype being "a fallen woman," to naming her "A Pure Woman" when, after long consideration, he decided to confront the reader immediately with this declaration in the subtitle: Tess of the d'Urbervilles: A Pure Woman.

Far from the Madding Crowd also deals with the concept of purity but in the man, Gabriel Oak. Oak is more 
traditionally natural than Tess in the sense of being pure in his actions as he follows prescribed dogma. He is similar to Tess in being the character most in harmony with nature. For example, as pointed out earlier in this thesis, Gabriel is the character who reads the signs from nature before the electrical storm and is also the only person who can save Bathsheba's sheep when they become sick. Hence, Gabriel is consistent in conventional concepts of what is deemed "natural" and "good" in relationship to nature and to society. On the other hand, Tess poises a problem to nineteenth-century interpretation of "pure" and "good" and will therefore be the focus of this conclusion.

Hardy struggles in Tess with the idea of maintaining Tess's individuality against the pressure of society's stereotyping her as an unwed mother. Kathleen Blake in her article "Pure Tess: Hardy on Knowing a Woman" points out the idea of the marginless landscape upon which Tess is often set by men and how she tries to fight this stereotype. Blake points to the way Tess struggles to keep her uniqueness in a society, which forces her into a landscape where she loses her identity:

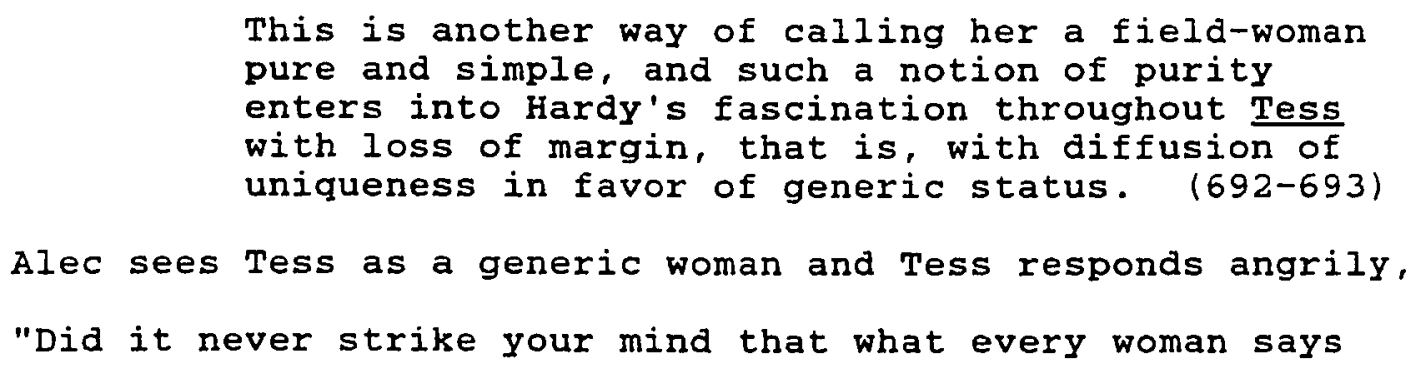

Alec sees Tess as a generic woman and Tess responds angrily, "Did it never strike your mind that what every woman says 
some women feel" (97). Also, Angel wanted to see her as a generic female when he calls her by the mythic names of Artemis and Demeter but Tess asks him not to call her by those classical names she can not understand.

In Far from the Madding Crowd, Gabriel is the purest of the characters and he, too, has the closest relationship with nature. By contrast, Bathsheba, Troy and Boldwood seem somewhat awkward and unsure of themselves in the rural setting, and thus less natural. However, Gabriel is a more conventional symbol of purity than Tess in the later novel. His actions do not contradict society. Hence, his obvious easy responses to the beauties and dangers of nature come from his natural relationship with his surroundings. Fanny Robin in the earlier novel is the closest to Tess in her role as an unwed mother. However, Hardy does not seem to want to challenge society by portraying Fanny as being both the "sinner" and at the same time "pure woman of nature." Hence, Far from the Madding Crowd is a more traditional view of a natural woman caught in the human dilemma. He encourages the reader to re-examine God-centered values in Tess by making Tess both the stained woman as well as a pure one.

Darwinism, which was of interest to Hardy, represents a heartless existence because to be good in Darwin's sense one would have to be cruel. The physical necessity of Darwinism of "survival of the fittest" implies that the stronger will 
survive the weaker. The laws of scarcity in Darwinian terms create a natural but ruthless world. Hence, Darwinism was essentially a physical explanation of the world, whereas in Tess, Hardy was struggling for a view which would integrate the physical with the spiritual.

However, Tess shows that Hardy did not want to continue to embrace the conventional and traditional values of the classics and religion, which created the danger of adherence to authoritarian thinking through non-dissenting views toward parents, religion and social mores. Hardy wanted to develop a world where individuals looked at each other eye to eye rather than on different levels depending on positions in society.

Angel is a prime example of this. Angel learns too late that it is Tess's intention to do good that determines her character, not a single incident where she becomes sexually stained when seduced/raped by Alec. Tess is generally good intentioned throughout the novel until the point where she kills Alec. As a young woman she often tries to help her family, but all too often circumstance or accident makes a bad situation worse. For example, she is trying to help the family when Prince, the horse, is killed. Later on she is trying to continue to help the family financially when she goes to the d'Urberville home. Tess expresses her desire to do something good for the family, but the coincidence of the presence of Alex's presence there will be her 
downfall :

'Well, as I killed the horse, mother,' she
said mournfully. 'I suppose I ought to do some-
thing. I don't mind going and seeing her, but
you must leave it to me about asking for help.
And don't go thinking about her making a match
for me--it is silly.'

Again, when she puts the letter warning Angel of her past

under his door she is trying to do the right thing.

The seduction/rape of Tess by Alec has the obscurity of

fog because Hardy is intentionally trying to confound the

scene to obscure Tess and raise the question: Is Tess

moving from a pure state of virginity to an impure one, or

does the fog actually obscure her movement from the unnat-

ural state of virginity to the more natural state of active

sexuality as in the animal world?

Tess and Alec are in an unspoiled or pristine environ-

ment when she loses her virginity. In fact, this has been a

natural environment for centuries as "above them rose the

primeval yews and oaks of The Chase" (119). Hardy asks the

question, "Why it was upon this beautiful feminine tissue,

sensitive as gossamer, and practically blank as snow as yet,

there should have been traced such a coarse pattern as it

was doomed to receive?" (119). The "coarse pattern" was "an

immeasurable social chasm [that] was to divide our heroine's

personality thereafter from the previous self of hers"

(119). As a woman Tess receives the "coarse pattern" of

pregnancy outside of marriage whereas the man's body as part 
of the double standard remains relatively unstained as far as society is concerned. There are no tell-tale signs for a sexually active male comparable to pregnancy. The question of what is pure and clean is obviously crucial for Hardy as he makes it the subtitle of his book "A Pure Woman." Hardy apparently feels that biblical sanctions do not determine purity. And when motivations arise from emotions or the will to do good, physical facts alone may not suffice to interpret actions fairly. Therefore, Hardy makes us consider Tess's will to do good and the emotional drive of family responsibility as opposed to the clear lustful intention of Alec.

Also the double standard in sexual behavior is important in looking at Tess's purity as a woman compared to a man. The wedding night of Tess and Angel clearly points out the difference in Victorian moral judgments on the conduct of man and woman when Angel shares his sexual past and Tess finds out that sexual purity for the woman is definitive but not for the man. The best we can say for Angel in this circumstance is that he is candid with his wife, but unaccepting of her. Kathleen Blake in her article "Pure Tess: Hardy on Knowing a Woman" indicates that Angel typecasts "Tess in terms of class, family, nature, and sex, but sexual typing exercises the most powerful sway" (696). Angel's visit to Brazil is important because in this exotic place some of the important philosophy around the 
issue of what the twentieth century calls " a double standard" can be freely explored by Hardy. The attractiveness for Angel of the South American country is that it lacks the social tradition and fixed standards of British society and thus becomes a transition point for Angel as he moves from traditional conventional thinking about Tess's sexual past to a freer interpretation. In fact his thinking is expressed in these terms:

Brazil somewhat attracted him as a new idea. Tess could eventually join him there, and perhaps in that country of contrasting scenes and notions and habits the conventions would not be so operative which made life with her seem impracticable to him here. In brief he was strongly inclined to try Brazil, especially as the season for going thither was just at hand. (333)

Hence, even before Angel goes to Brazil the reader senses he is looking for some place as a haven from conventional European societies' views of life. Instead of finding a place and a society compatible with English conventions, he finds an intellectual emotional place where he meets a "large-minded stranger" (422).

While in Brazil Angel is challenging the traditional question of "Who was the moral man? still more pertinently, who was the moral woman?" (421). Society underpinned by Hebraic-Christian morality gives us universal definitions of morality which may not always apply in particular situations. Angel learns that he has been "influenced by general principles to the disregard of the particular instance" 
(423). Hardy has Angel then ponder the issue that is central to the transformation from traditional explanations of the world to more modern scientific ones:

The beauty or ugliness of a character lay not only in its achievements, but in its aims or impulses; its true history lay, not among things done, but among things willed. (421)

Hence, one person may live the strict morality of the Bible and his motives in life may be unnatural, whereas, another person may depart from strict morality of the Bible yet be natura1, as in Tess's case. Hence, a person may be considered morally unclean or impure according to the Bible, but Hardy is suggesting that a person could be more natural or purer in intention than another who engages in biblically acceptable sexual practices, depending on what will drives each person or in what spirit it is done. This puts into focus the idea that society in the nineteenth century as well as today emphasizes virginity. However, actually a sexual active adult life may be the most natural. Hardy points out that the "large-minded stranger" views Tess in a different light:

He viewed the matter in quite a different light from Angel; thought that what Tess had been was of no importance beside what she would be, and plainly told clare that he was wrong in coming away from her. (422)

The stranger has a macroscopic view of Tess's transgression as compared to Angel's microscopic provincial view:

The stranger had sojourned in many more lands and among many more people than Angel; to his cosmopolitan mind such deviations from the social 
norm, so immense to domesticity, were no more than are the irregularities of vale and mountain-chain to the whole terrestrial curve. (422)

Hardy is using the scientific idea of the curvature of the earth to make his comparison with the importance of the perspective from which we view ideas. The large-minded stranger's analogy of margins and curvatures of the earth indicates that he sees Tess differently than Angel and Alec have. The margin that defines her transgression in society has disappeared for him and she has become part of a larger picture.

Hardy translates his indecisive hero Angel to Brazil in a quest for new land and opportunity. He also wanted to test Angel and his own ideas of morality in a more open and mixed society than that of Britain. And Hardy also evidentIy needed to test these ideas of morality in another setting than Wessex which he had developed as an ancient small district dominated by the homogeneity of its traditions, religion, small towns, country farm life and prejudices. In Wessex, all the characters seem to know each other to some degree--as relatives or friends or fellow-workers. Hardy chose a country in South America far across an ocean, a vast one whicir could be calculated to contrast on a broad spectrum with England.

Brazil was "discovered" by the Spanish and Portuguese with the Eastern half going first to Portugal by treaty with the spanish. In sixteenth- to seventeenth-century history 
the Portuguese threw back the French, Dutch, and British invaders. 1840 to 1889 was an era of great progress under Brazil's last monarch Pedro II. Meanwhile, in Europe Brazil (with great port cities such as Rio de Janeiro, the Amazon, reptiles, sugar and slave traders, gold and other metals) became a beckoning, diversified place in the lexicon of the world's romantic and exotic spots.

In addition to the physical attractions, the diversity, the colorful history, the many languages, there was the attraction of the collision of several European religions with a non-Hebraic/Christian group, the American Indians. In addition, the lushness of the rain forests and jungle of that area supplies a natural environment carrying suggestions of an uninhibited sexual vital force. Hence, the terrain itself carries in its unchecked growth of a freer environment where more flexible English morality may become compatible with the new country. Angel, looking for a place where British morality would be compatible with the new country, might find it in an atmosphere where local generic culture mixes with and modifies Roman Catholic/Anglican views of morality.

When Angel says that he is going to Brazil, his mother says, "Brazil! Why they are all Roman Catholics there surely" (334). Hardy goes on to speak of the "novelty and painfulness of going to a Papistical land" for Angel's parents. Interestingly, although Anglicans consider them- 
selves Protestants as Mercy Chant emphasizes in her comments with Angel, Catholicism and Church of England are actually very close except for the belief in the pope. In fact, the High Tractarians and oxford Movement wanted to return to greater catholicity. Mercy Chant expresses a concern with Roman Catholicism in her dialogue with Angel:

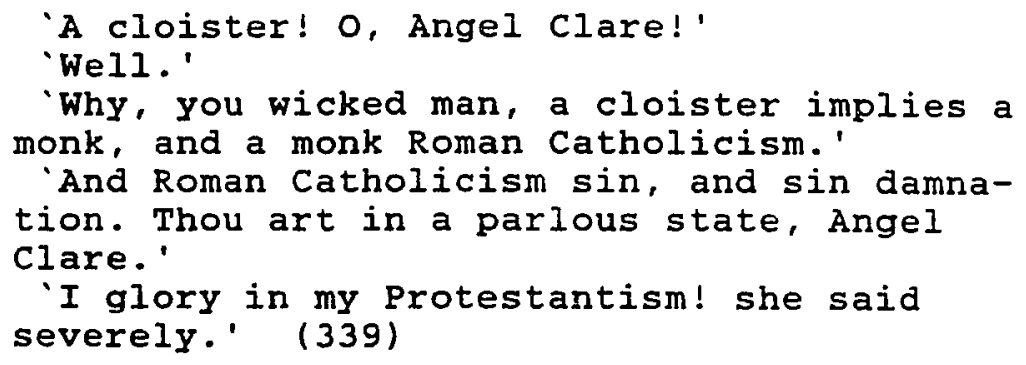

When Tess appears before Angel at Sandbourne she is not dressed very naturally:

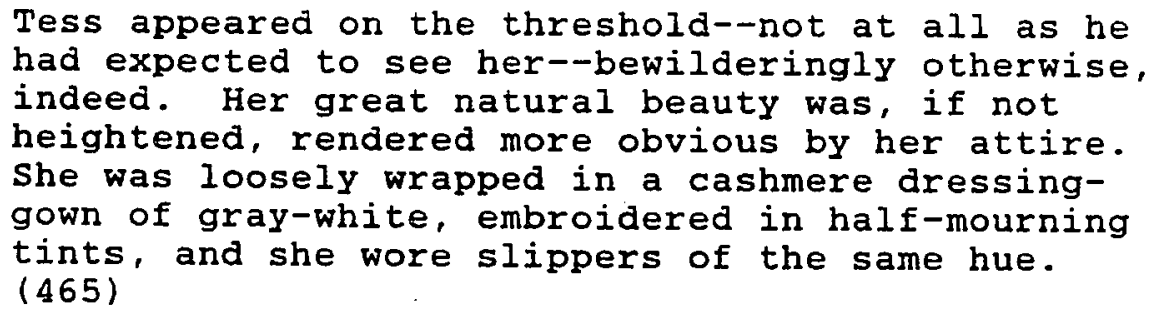

The grey-white hue of her gown implies that her purity has been stained.

Near the end of the novel, Tess emphasizes that Angel

should marry Liza-Lu if Tess dies. Liza-Lu's purity is

mentioned: "She is so good and simple and pure" (485).

This indicates a recognition by Hardy that Victorian society had not caught up with Tess and Angel. Even though Angel wants to forgive Tess for her early youthful transgression, 
she has in the meantime committed the crime of murder for which she cannot be forgiven by society. Hence, although Hardy does not try for a final definition of purity, the reader senses that someone like Liza-Lu who is natural and sexually pure is among the only ones who can survive in Victorian society. In giving primacy to "natural," instinctual behavior over social mores, Hardy pointed himself toward the twentieth century. Instead of holding onto stereotypical reactions, a natural person recognizes the variety of nature and responds to the individual incident rather than to a predetermined dogmatic view of the world. 
WORKS CITED

Ainsworth, William Harrison. Rookwood. Everyman's Library 870. 1834. London: Dent, 1952.

Alexander, Peter. "The Philosophy of Science, 1850-1910." A Critical History of Western Philosophy. 1964. Ed. D. J. O'Connor. New York: The Free Press-Macmillan, 1985.

Armour, Richard. English Lit Relit. New York: McGraw, 1969.

Arnold, Matthew. "Hebraism and Hellenism." Culture and Anarchy: An Essay in Political and Social Criticism. Ed. Ian Gregor. Indianapolis: Bobbs-Merrill, 1971.

Beer, Gillian. Darwin's Plots: Evolutionary Narrative in Darwin, George Eliot and Nineteenth-Century Fiction. London: Routledge \& Kegan Paul, 1983.

Benét, William Rose. Benét's Reader's Encyclopedia, 2nd ed. New York: Harper, 1965.

Berger, Sheila. Thomas Hardy and Visual Structures: Framing, Disruption, Process. New York: New York UP, 1990.

Björk, Lennart A. "Hardy's Phychological Vision and 'Hellenic' Social Criticism." Psychological Vision and Social Criticism in The Novels of Thomas Hardy. Almqvist and Wiksell, 1987.

---. "Thomas Hardy's 'Hellenism." Gothenburg Studies in Enqlish 60 (1985): 46-58.

Blake, Kathleen. "Pure Tess: Hardy on Knowing a Woman." Studies in English Literature 1500-1900 22 (1982) $689-705$.

Bond, Francis. Gothic Architecture in England: An Analysis of the Origin and Development of English Church Architecture from the Norman Conquest to 
the Dissolution of the Monasteries. 1905. New York: Books for Libraries, 1972 .

Byatt, A.S. Passions of the Mind. New York: Random House, 1992 .

Casagrande, Peter J. Unity in Hardy's Novels: 'Repetitive Symmetries.' Lawrence: The Regents P of Kansas, 1982.

Chapple, J.A.V. Science and Literature in the Nineteenth Century. London: Macmillan, 1969.

Cox, J. Stevens, ed. The Library of Thomas Hardy. St. Peter Port, Eng.: Toucan Press, 1969.

Cuddon, J.A. A Dictionary of Literary Terms. Garden City: Doubleday, 1976 .

Daiches, David and John Flower. Literary Landscapes of the British Isles. New York: McGraw, 1979.

Darwin, Charles. The Descent of Man and Selection in Relation to sex. 1874. Detroit: Gale, 1974.

-- On the origin of Species by Natural Selection. 1859. New York: Heritage Press, 1963.

Eakins, Rosemary L. "Tess: The Pagan and Christian Traditions." The Novels of Thomas Herdy. Ed. Anne Smith. New York: Harper, 1979.

Enstice, Andrew. Thomas Hardy, Landscapes of the Mind. New York: St. Martin's, 1979.

Firor, Ruth A. Folkways in Thomas Hardy. New York: Barnes, 1931.

Freeman, Janet. "Ways of Looking at Tess." Studies in Philology 79 (1982): 311-323.

"Gargoyle." Oxford English Dictionary. 1989 ed.

Garson, Marjorie. Hardy's Fables of Integrity: Woman, Body, Texts. Oxford: CIaxendon Press, 1991.

Goode, John. Thomas Hardy: The Offensive Truth. Oxford: Clarendon Press, 1991.

Gosse, Elliott B., Jr. "Psychic Evolution: Darwinism and 
Initiation in Tess of the d'Urbervilles" NineteenthCentury Fiction 18 (1963) 261-72.

Gray, Thomas. "Elegy Written in a Country Churchyard." Norton Anthology of English Literature. Ed. M.H. Abrams. 5th ed. New York: Norton, 1986. 2480-3.

Hands, Timothy. "'A Bewildered Child and His Conjurors': Hardy and the Ideas of His Time." Thomas Hardy

Conference. Dorchester Eng., 31 July 1992.

--. Thomas Hardy: Distracted Preacher?: Hardy's Religious Biography and Its Influence on His Novels. New York: St. Martin's 1989.

Hardy, Florence Emily. The Early Life of Thomas Hardy, 1840-1891. New York: Macmillan, 1933.

--. The Later Years of Thomas Hardy, 1892-1928. New York: Macmillan, 1933.

Hardy, Thomas. Far from the Madding Crowd. 1874. New York: Viking Penguin, Inc., 1978.

--. Literary Notebooks of Thomas Hardy. Ed. Lennart A. Björk. Vol. 2. New York: New York UP, 1985. 2 vols.

--. Poems. Selections. Ed. John Crowe Ranson. New York: Macmillan, 1961.

--. Tess of the d'Urbervilles. 1891. New York: Penguin Group, 1978.

---. Thomas Hardy's Notebooks: And Some Letters from Julia Augusta Martin. Ed. Evelyn Hardy. London: Hogarth Press, 1955.

--. Two on a Tower. 1912. London: Macmillan, 1920.

Harrison, Frederic. Letter to Thomas Hardy. 29 December 1891. Hardy Memorial Collection. Dorset County Museum, Dorchester.

Hoffmeister, Gerhart. European Romanticism: Literary CrossCurrents, Modes, and Models. Detroit: Wayne state UP, 1990.

Holloway, John. "Hardy's Major Fiction." From Jane Austen to Joseph Conrad. Ed. Robert C. Rathburn and 
Martin Steinmann, Jr. Minneapolis: U of Minnesota P, 1958. 234-45.

Horne, Lewis. "Passion and Flood in Far from the Madding Crowd." Ariel 13 (1982): 39-49.

Irvine, William. Apes, Angels, \& Victorians: The Story of Darwin, Huxley, and Evolution. 1955. New York: Time Inc., 1963.

Jeans, James, Sir. The Mysterious Universe. 1930. New York: Macmillan, 1933.

Jenkyns, Richard. The Victorians and Ancient Greece. Cambridge: Harvard UP, 1980.

Kelly, Mary Ann. "Hardy's Reading in Schopenhauer: Tess of the d'Urbervilies." Colby Library Quarterly 18 (1982) 183-198.

LeCercle, Jean Jacques. "The Violence of Style in Tess of the d'Urbervilles." Alternative Hardy. Ed. Lance St. John Butler. New York: St. Martin's, 1989.

Miller, J. Hillis. "Fiction and Repetition: Tess of the d'Urbervilles." Forms of Modern British Fiction. Austin: U of Texas P, 1975. 43-71.

Moore, Kevin $z$. The Descent of the Imagination: Postromantic Culture in the Later Novels of Thomas Hardy. New York: New York UP, 1990.

Orel, Harold, ed. Thomas Hardy's Personal Writings: Prefaces, Literary Opinions, Reminiscences. Lawrence: U of Kansas P, 1966.

Pinion, F. B. "Hardy and Myth." Thomas Hardy: Art and Thought. Totowa, NJ: Rowman, 1977.

--. A Hardy Companion: A Guide to the Works of Thomas Hardy and Their Background. London: Macmillan, 1968 .

Rutland, William $R$. Thomas Hardy: A Study of His Writings and Their Backqround. Oxford: Basil Blackwell, 1938 .

Stevenson, Lionel. "Thomas Hardy." Darwin among the Poets. Chicago: U of Chicago P, 1932 . 
Taylor, Richard. "Schopenhauer." A Critical History of Western Philosophy. 1964. Ed. D.J. O'Connor. New York: The Free Press-Macmillan, 1979.

Webb, Beatrice. My Apprenticeship. 1926. Cambridge: Press Syndicate of the $U$ of Cambridge, 1979.

Webster, Harvey Curtis. On a Darkling Plain. Chicago: $U$ of Chicago P, 1947.

Widdowson, Peter. Tess of the d'urbervilles. New Casebooks 11. New York: St. Martin's, 1993.

Wike, Jonathan. "Hintock by Bicycle: Wessex as Critical Orientation." The Thomas Hardy Journal 8 (1992): 5562 .

Woolf, Virginia. The Novels of Thomas Hardy. New York: Harcourt, 1960 . 